University of Nebraska - Lincoln

DigitalCommons@University of Nebraska - Lincoln

Faculty Publications from the Harold W. Manter Laboratory of Parasitology

10-1952

\title{
Studies on the Helminth Fauna of Alaska. XI. Helminth Parasites of Microtine Rodents--Taxonomic Considerations
}

Robert L. Rausch

Arctic Health Research Center, rausch@u.washington.edu

Follow this and additional works at: https://digitalcommons.unl.edu/parasitologyfacpubs

Part of the Parasitology Commons

Rausch, Robert L., "Studies on the Helminth Fauna of Alaska. XI. Helminth Parasites of Microtine Rodents--Taxonomic Considerations" (1952). Faculty Publications from the Harold W. Manter Laboratory of Parasitology. 559.

https://digitalcommons.unl.edu/parasitologyfacpubs/559

This Article is brought to you for free and open access by the Parasitology, Harold W. Manter Laboratory of at DigitalCommons@University of Nebraska - Lincoln. It has been accepted for inclusion in Faculty Publications from the Harold W. Manter Laboratory of Parasitology by an authorized administrator of DigitalCommons@University of Nebraska - Lincoln. 


\section{STUDIES ON THE HELMINTH FAUNA OF ALASKA. XI. HELMINTH PARASITES OF MICROTINE RODENTS-TAXONOMIC CONSIDERATIONS}

\section{Robert Rausch*}

A survey of the helminth parasites of Alaskan rodents has been carried on by the writer since the winter of 1948-49, as a continuation of an investigation begun in the central United States in 1942. Results of this work indicate that, despite the size of the Territory of Alaska, the survey is complete enough to furnish a reasonable knowledge of the species of helminths parasitic in microtine rodents in Alaska. Information derived from previous investigations serves as a standard against which the completeness of the present work may be judged. In the writer's opinion, the continuation of this work on a survey basis is impractical, and it is the purpose of this paper to report qualitatively the results obtained to date. Main emphasis has been placed here on the taxonomic consideration of the helminth species collected. Ecological and zoogeographical observations will be presented in another publication.

Most of the rodents autopsied in connection with this investigation were collected in Alaska. The material was supplemented whenever possible by rodents from northern Canada and Eurasia.

Only rodents of the subfamily Microtinae are considered. A total of 2078 individuals of 26 species and subspecies, representing five genera, has been examined. These comprise the lemmings (Dicrostonyx and Lemmus), the bog lemmings (Synaptomys), the red-backed voles (Clethrionomys), and voles of the genus Microtus. Nearly all host identifications have been made by the writer, mainly through comparisons with specimens in the collections of the U. S. National Museum, the U. S. Biological Survey, and others. Most of the material from Canada and Eurasia was identified before it came into the hands of the writer.

North American rodents considered in this investigation are listed in Table 1, with brief notations on localities from which they were collected. The map of northern North America (Fig. 1) shows specific collection localities.

The helminthological investigation has been approached from the standpoint of host relationships and distribution, in order to take advantage of obvious faunal relationships and zoogeographical knowledge. Studies of this type are complicated in boreal regions by a tendency toward circumpolar faunal uniformity. Some rodents considered herein are clearly of circumpolar distribution; others are of rather indefinite status, since possible affinities with Palearctic forms have not been elucidated; a few species are Nearctic in their distribution, or at least they have no closely-related Eurasian counterparts. The mouse-like rodents of the subfamily Microtinae form a homogeneous group when considered in the light of their immunophysiological relationships with the helminths parasitizing them, as exemplified by little development of host-parasite specificities. These points will be discussed, more appropriately, in another publication.

Received for publication, March 5, 1952.

* Animal-borne Disease Branch, Arctic Health Research Center, U. S. Public Health Service, Anchorage, Alaska. 
Rausch in Journal of Parasitology (October 1952) v. 38, no. 5.

Copyright 1952, American Society of Parasitologists. Used by permission.

TABLE 1.-Microtine Rodents Examined for Parasites from Arctic and High Boreal Regions of North America

\begin{tabular}{|c|c|c|c|}
\hline No. & Name & $\begin{array}{l}\text { Number } \\
\text { examined }\end{array}$ & Source \\
\hline 1 & $\begin{array}{l}\text { Dicrostonyx groenlandicus } \\
\text { groenlandicus (Traill) }\end{array}$ & 3 & Smith Sound, Greenland \\
\hline 2 & D. groenlandiculs rubricatus & 30 & $\begin{array}{l}\text { Arctic Alaska : Wainwright, Point Barrow, Lake } \\
\text { Schrader, central Brooks Range }\end{array}$ \\
\hline $\begin{array}{l}\mathbf{3} \\
\mathbf{4} \\
\mathbf{5} \\
\mathbf{6} \\
\mathbf{7} \\
\mathbf{8}\end{array}$ & $\begin{array}{l}\text { D. groenlandicus richardsoni Merriam } \\
\text { D. groenlandicus exsul Allen } \\
\text { D. groenlandicus ssp. } \\
\text { D. hudsonius (Pallas) } \\
\text { Synaptomys borealis dalli Merriam } \\
\text { Lemmus trimucronatus } \\
\text { trimucronatus (Richardson) }\end{array}$ & $\begin{array}{l}\mathbf{1} \\
\mathbf{3} \\
\mathbf{5} \\
\mathbf{4} \\
\mathbf{1}\end{array}$ & $\begin{array}{l}\text { Churchill, Manitoba } \\
\text { St. Lawrence Island } \\
\text { Prince Patrick Island (Canadian western Arctic) } \\
\text { Chimo, Ungava } \\
\text { Extreme northwestern British Columbia } \\
\text { Melville Peninsula and Chesterfield Inlet, Canada }\end{array}$ \\
\hline 9 & L. trimucronatus alascensis (Merriam) & 216 & $\begin{array}{l}\text { Arctic Alaska: Wainwright, Point Lay, Point } \\
\text { Barrow, Lake Schrader, central Brooks Range }\end{array}$ \\
\hline $\begin{array}{l}10 \\
11 \\
12\end{array}$ & $\begin{array}{l}\text { L. trimucronatus harroldi (Swarth) } \\
\text { L. nigripes True }\end{array}$ & $\begin{array}{r}85 \\
1\end{array}$ & $\begin{array}{l}\text { Nunivak Island } \\
\text { St. George Island, Pribilofs }\end{array}$ \\
\hline 13 & $\begin{array}{l}\text { C. rutilus albiventer }{ }^{2} \mathrm{Hall} \text { and Gilmore } \\
\text { C. wrangeli Bailey }\end{array}$ & $\begin{array}{r}240 \\
3 \\
11\end{array}$ & $\begin{array}{l}\text { and Lake Schrader-over most of Territory } \\
\text { St. Lawrence Island } \\
\text { Southeastern Alaska (Juneau) }\end{array}$ \\
\hline 10 & Microtus oeconomus operarius Nelson & 324 & $\begin{array}{l}\text { Western Alaska: North as far as Point Lay, on } \\
\text { Arctic Coast }\end{array}$ \\
\hline 16 & M. oeconomus macfarlani Merriam & 203 & $\begin{array}{l}\text { Eastern } 2 / 3 \text { of Territory: north as far as Umiat, } \\
\text { on Colville River, and Lake Schrader }\end{array}$ \\
\hline $\begin{array}{l}17 \\
18 \\
19 \\
20 \\
21\end{array}$ & $\begin{array}{l}M . \text { oeconomus innuitus Merriam }{ }^{3} \\
M . \text { oeconomus ladiacensis Merriam } \\
M . \text { oeconomus yakutatensis Merriam } \\
M . \text { oeconomus ssp. } 4 \\
M . \text { pennsylvanicus drumondii }\end{array}$ & $\begin{array}{r}585 \\
9 \\
4 \\
\mathbf{2}\end{array}$ & $\begin{array}{l}\text { St. Lawrence Island } \\
\text { Kodiak Island } \\
\text { Southeastern Alaska : Haines and Valdez } \\
\text { Alaska Peninsula (Cold Bay) }\end{array}$ \\
\hline & (Audubon and Bachman) & 20 & Eastern Alaska ; Fort Rae, District of Macke \\
\hline $\begin{array}{l}22 \\
23 \\
24\end{array}$ & $\begin{array}{l}M . \text { longicaudus vellerosus Állen } \\
M . \text { longicaudus littoralis Swarth } \\
M . \text { miurus oreas Osgood }\end{array}$ & $\begin{array}{l}6 \\
9 \\
6\end{array}$ & $\begin{array}{l}\text { Extreme northwestern British Columbia } \\
\text { Southeastern Alaska (Juneau) } \\
\text { McKinley Park }\end{array}$ \\
\hline 25 & M. miurus paneaki Rausch & 300 & $\begin{array}{l}\text { Arctic Alaska: Anaktuvuk Pass region of Brooks } \\
\text { Range; Umiat on Colville River; Arctic Vil- } \\
\text { lage; Lake Schrader }\end{array}$ \\
\hline 26 & M. miurus ssp. & 1 & Talkeetna Mountains, near Anchorage \\
\hline
\end{tabular}

1 Hitherto known as D. exsul Allen, the writer considers this but a subspecies of $D$. groenlandicus. The study of pertinent material has failed to disclose significant structural differences. According to Ognev (1948; pp. 474-510), D. groenlandicus should be considered a subspecies of the Palearctic D. torquatus Pallas. A full discussion of this problem is presented elsewhere.

2 Recent work (Rausch, 1950) has proved the red-backed vole of the Alaskan mainland conspecific with the Palearctic $C$. rutilus. The study of St. Lawrence Island material has failed to disclose structural or other characters of specific value. C. albiventer Hall and Gilmore is consequently treated here as a subspecies of $C$. rutilus. Full details will be presented in another publication.

3 Of these, 493 animals were examined for Echinococcus larvae only.

4 According to recent nomenclatural changes, the specimens of Microtus oeconomus from Point Lay should be designated as Microtus oeconomus gilmorei Setzer, 1952, (Proc. Biol. Soc. Wash. 65:75-76), and the Alaskan specimens of Microtus pennslyvanicus probably are referable to the form Microtus pennsyvlanicus tananaensis Baker, 1951, (U. Kans. Publ. Mus. Nat. Hist. 5 : 107-108).

In order to simplify reference to the literature, in some cases a brief consideration of the helminth genus is presented before the species are discussed. Detailed morphological data are not included except where it is thought necessary for clarification of a taxonomic problem.

\section{CESTODA}

\section{Genus Paranoplocephala Lühe, 1910}

Important among the helminth parasites of North American microtine rodents are cestodes of the genus Paranoplocephala. Material obtained during the course of this investigation has been adequate in amount to permit restudy of certain members of the genus. This undertaking has been profitable, since a better concept of speciation within the genus has been attained. 


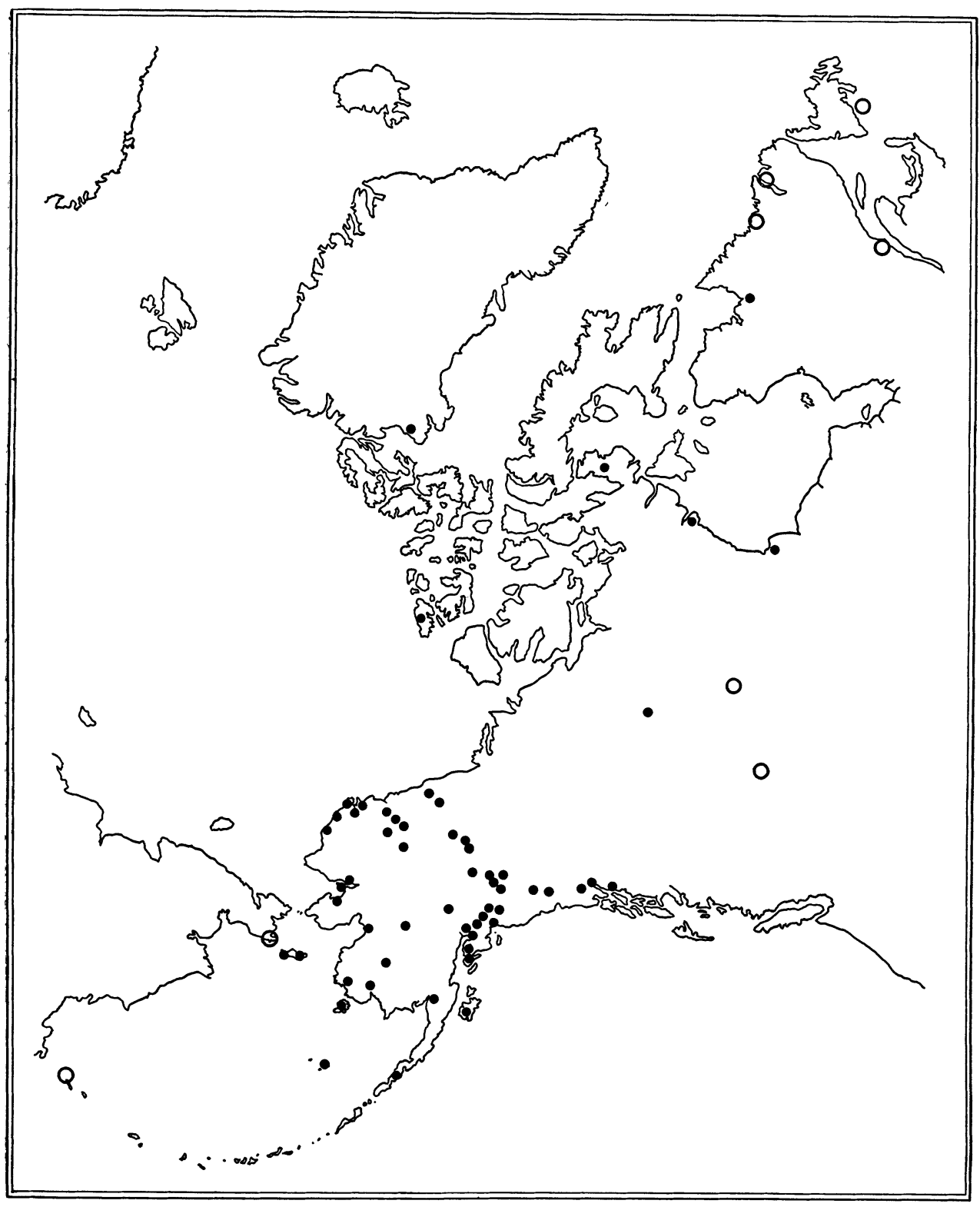

FIG. 1. Localities from which microtine rodents were examined for helminth parasites. Rodents listed in Table 1 were collected from localities represented by solid symbols. Hollow symbols represent collections of rodents whose parasites were studied but not considered specifically in this paper.

Douthitt (1915) was the first to study vole cestodes in the United States. He described two species of Paranoplocephala-P. infrequens (Douthitt, 1915) and P. variabilis (Douthitt, 1915). Baer (1927), in his monograph of the AnoplocePHALIDAE, considered $P$. variabilis identical with $P$. infrequens. An attempt by Rausch and Schiller (1949a) to clarify the status of certain vole parasites resulted in the discovery that $P$. infrequens was incorrectly characterized, and further that 
$P$. infrequens and $P$. variabilis are morphologically distinct. Rausch and Schiller synonomized $P$. troeschi Rausch, 1946, with $P$. infrequens, and at the same time elevated Douthitt's variety, $P$. variabilis borealis, to full specific rank. Baer (1949) reviewed the genus and redescribed $P$. isomydis (Setti, 1892). He also separated the genus into two groups on the basis of the presence or absence of an external seminal vesicle. Voge, in a journal published for 1948, but which appeared after the papers by Rausch and Schiller and by Baer had been published in 1949, described P. kirbyi Voge, 1948. P. omphalodes (Hermann, 1783) has been recorded twice by North American workers (Harkema, 1946; Rausch, 1951). The most recent addition to the group is $P$. neofibrinus Rausch, 1952. Before the Alaskan species of Paranoplocephala are discussed, it is necessary to review some of the foregoing records.

To the time of this writing, $P$. infrequens, $P$. variabilis, $P$. borealis, and the recently described $P$. neofibrinus have been considered valid species. Although mentioned earlier in another publication (Rausch, 1952), it is necessary to point out here that $P$. kirbyi is a synonym of Andrya macrocephala Douthitt, 1915 . The description of $P$. kirbyi, from Microtus californicus, was completed before the publication of a study on variation in A. macrocephala by Rausch and Schiller (1949b). The examination of type and paratype material, by the present writer, disclosed that these cestodes agree in all morphological details with $A$. macrocephala. The uterus type as portrayed by Voge (1948; Fig. 2) is correct for Paranoplocephala. Since the present writer's examination of the material failed to disclose anything but the typical reticulate uterus of $A n d r y a$, it is assumed that this structure was not correctly interpreted. With the exception of this character, nothing in the description of $P$. kirbyi serves to differentiate it from $A$. macrocephala. It is to be noted that Voge's statement (page 302) could hardly apply to uterus formation in Paranoplocephala: "In more posterior mature segments the ends of the uterine tubes become forked and the main tubes give off side branches." The uterus in Paranoplocephala characteristically develops through the formation of anterior and posterior sacculations from the simple, transverse tube which comprises the uterus in the mature segments. Except for P. omphalodes, discussed below, all species of Paranoplocephala recorded from North American hosts possess anteriorly attenuated, more or less wedge-shaped strobilae.

\section{Paranoplocephala infrequens (Douthitt, 1915)}

Paranoplocephala infrequens is a common cestode parasite of voles in the United States, and is adapted to existence in the cecum of these animals. It is observed frequently in microtine rodents in Alaska, where abundant material has been obtained. This species was studied in detail by Rausch and Schiller (1949a), and comparisons made by them indicated that the Eurasian $P$. brevis Kirschenblatt, 1938, is a closely related, if not identical, form. Material obtained in connection with the present study allows some elaboration of the earlier work, although $P$. infrequens is a well characterized species. The writer has studied cestodes of this species collected from various hosts over much of North America. The geographic origin of this material can be outlined briefly as follows: From the Mogollon Mountains, Arizona, north to the Arctic Coast of Alaska; from Long Island, New York, west to the Teton Mountains of Wyoming. Specimens have been obtained from various 
points lying within these extremes. There is, however, a lack of material from southern and eastern Canada.

Material collected over the United States, nearly all from Microtus spp. is relatively uniform. Strobila length ranges from 4 to $11.5 \mathrm{~mm}$. (fully "adult" specimens, with gravid segments and evidence of terminal segment loss). Most of these cestodes range from 5 to $7 \mathrm{~mm}$. in length (average: $6 \mathrm{~mm}$.). The strobila has a characteristic wedge-shape, with the greatest width, usually about $2 \mathrm{~mm}$., attained at the posterior end. The internal detail is essentially as described (Rausch and Schiller, 1949b), but degree of variation in egg size may differ considerably from one locality to another.

About 50 specimens of $P$. infrequens from various hosts and localities within Alaska were stained and mounted for study. It was found that the Alaskan specimens correspond closely in morphological details to those collected much farther south. The average strobila size may be larger, but this does not appear to be

TABLE 2.-Measurements of Paranoplocephala infrequens (Douthitt, 1915) from North American Hosts

\begin{tabular}{|c|c|c|c|c|c|c|}
\hline \multirow{2}{*}{ Host } & \multirow{2}{*}{ Locality } & \multirow{2}{*}{$\begin{array}{l}\text { Strobila } \\
\text { length } \\
\text { (in } \mathrm{mm} . \text { ) }\end{array}$} & \multirow{2}{*}{$\begin{array}{l}\text { Greatest } \\
\text { strobila } \\
\text { width } \\
(\mathrm{mm} .)\end{array}$} & \multirow{2}{*}{$\underset{\text { ment }}{\text { Seg- }}$ number } & \multicolumn{2}{|c|}{$\begin{array}{c}\text { Egg size } \\
\text { (in microns) }\end{array}$} \\
\hline & & & & & Range & $\begin{array}{l}\text { Aver- } \\
\text { age }\end{array}$ \\
\hline $\begin{array}{l}\text { Microtus pennsylvanicus } \\
\text { pennsylvanicus (Ord) }\end{array}$ & Long Island, New York & 6.5 & 2 & 45 & $32-35 \times 20-30$ & $33 \times 26$ \\
\hline $\begin{array}{l}\text { M. pennsylvanicus } \\
\text { pennsylvanicus (Ord) }\end{array}$ & Ohio & $5.5-6$ & 2 & $41-44$ & $33-42 \times 23-30$ & $36 \times 29$ \\
\hline $\begin{array}{l}\text { M. pennsylvanicus } \\
\text { pennsylvanicus (Ord) }\end{array}$ & Michigan & $5-7.5$ & $2-2.5$ & $39-48$ & $42-56 \times 23-49$ & $47 \times 31$ \\
\hline $\begin{array}{l}\text { M. pennsylvanicus } \\
\text { pennsylvanicus (Ord) }\end{array}$ & Wisconsin & $5-7$ & $1.2-2$ & 30-31 & $36-56 \times 29-52$ & $48 \times 41$ \\
\hline $\begin{array}{l}\text { M. pennsylvanicus drum- } \\
\text { mondii (Aububon and } \\
\text { Bachman) }\end{array}$ & Skwentna River, Alaska & $5.7-6.5$ & $1.5-2$ & 31-33 & $33-39 \times 26-29$ & $35 \times 28$ \\
\hline $\begin{array}{l}\text { M. pennsylvanicus } \\
\text { modestus (Baird) }\end{array}$ & Wyoming & $5-6$ & $1.2-1.5$ & 28-32 & $35-46 \times 27-43$ & $42 \times 37$ \\
\hline$M . \underset{\text { Merriam }}{\text { montanus nanus }}$ & Wyoming & $5-7$ & $2-3$ & $29-36$ & $36-49 \times 26-42$ & $45 \times 35$ \\
\hline M. $\underset{\text { Merriam }}{\text { richardsoni macropus }}$ & Wyoming & $4-7$ & 2.5 & $26-42$ & $35-51 \times 35-40$ & $45 \times 38$ \\
\hline M. mogollonensis Mearns & Arizona & 6-7 & $1.7-2$ & 32-35 & $39-46 \times 29-36$ & $43 \times 31$ \\
\hline M. miurus paneaki Rausch & $\begin{array}{c}\text { Anaktuvuk Pass, Brooks } \\
\text { Range, Alaska }\end{array}$ & $7-9$ & $3.1-4$ & $41-42$ & $36-49 \times 29-46$ & $44 \times 36$ \\
\hline M. miurus paneaki Rausch & Lake Schrader, Alaska & $7-7.5$ & $2-2.7$ & $41-42$ & $43-51 \times 37-50$ & $46 \times 42$ \\
\hline $\begin{array}{l}\text { M. oeconomus macfarlani } \\
\text { Merriam }\end{array}$ & $\begin{array}{c}\text { Anaktuvuk Pass, Brooks } \\
\text { Range, Alaska }\end{array}$ & $6-7.5$ & $\mathbf{2 - 3}$ & $32-42$ & $39-66 \times 36-56$ & $55 \times 46$ \\
\hline
\end{tabular}

significant. There is, however, the tendency toward greater local variation in egg size. Cirrus sac size is variable, as is testes number. Testes distribution, on the other hand, appears to be a rather important specific character if minor differences are not emphasized.

In order to compare cestodes of this species from various hosts and from various parts of North America, important measurements and other details have been presented in Table 2 .

It is possible to draw the following conclusions from present knowledge of $P$. infrequens:

1. Strobila size is not related to host-species occurrence.

2. Morphological differences cannot be correlated with host-species occurrence.

3. Egg size is highly variable in $P$. infrequens; both size-range and average size may differ considerably from one locality to another. 
Rausch in Journal of Parasitology (October 1952) v. 38, no. 5.

Copyright 1952, American Society of Parasitologists. Used by permission.

4. Although specimens from Alaska seem more variable locally and average somewhat larger in size, there is no apparent cline formation.

\section{Paranoplocephala borealis (Douthitt, 1915)}

When one studies a good series of cestodes corresponding morphologically to the description of $P$. borealis, it becomes apparent that only specimens of a uniform state of development are included. Douthitt (1915) was of the opinion that a graded variation from south to north existed, involving strobila size and certain internal structures. In this regard he stated (1915; p. 23): “As one passes northward, however, it is found that the individuals grow steadily smaller, both in bulk and number of proglottids. In anatomical features only one difference was discerned: the testes become very regularly fewer. ... The most conspicuous difference between the worms from the different localities is in size; those from the north being only about half the length and breadth of those from the south." Rausch and Schiller (1949a) did not observe morphological intergradation of $P$. variabilis and $P$. borealis in their material from the Great Lakes region. It was thought by them that two distinct species were involved, on the basis of characters considered at that time to have specific value. Douthitt, on the other hand, stated, in reference to his table (page 24), that ". . . while there is a considerable difference between the extremes, the intergradations are sufficiently regular to destroy the validity of these differences as specific characteristics." Except for a small amount of Douthitt's original material, mostly in the form of serial sections, the writer has not examined any specimens from the type host, Geomys bursarius Shaw, in which $P$. borealis is reported to occur in large numbers per individual animal.

In Alaska, particularly in the central Brooks Range and in the south along the Skwentna River, a good series of the P. borealis type was collected. It is evident from this material that specimens classified as $P$. borealis represent young cestodes in which fully-formed eggs are just appearing. This impression is supported by the persistence of the original terminal segment until the strobila in some cases has reached a length as great as $8 \mathrm{~mm}$., and the loss of the terminal segment alone in strobilae up to $15 \mathrm{~mm}$. in length. Some strobilae, on the other hand, may lose terminal segments by the time a length of $5 \mathrm{~mm}$. is attained, there being no consistency in this feature.

Specimens typical of $P$. borealis have been obtained by the writer from the following hosts and localities, in addition to the Alaskan material: Microtus $p$. pennsylvanicus Ord, from Wisconsin, Ohio, and southern Illinois; $M$. ochrogaster (Wagner), from Nebraska; Synaptomys cooperi Baird, from southern Illinois; Thomomys talpoides tenellus Goldman, from Jackson Hole, Wyoming; Microtus sp. from Oregon. There is striking uniformity in these specimens, despite their wide geographic distribution.

There are two anatomical details, however, which require further mention if the identity of the Alaskan cestodes is to be established; these are cirrus spination and egg size.

Douthitt $(1915$; p. 21$)$, in regard to $P$. variabilis, stated, "The cirrus is not spiny." This was verified by Rausch and Schiller (1949a) for both $P$. variabilis and $P$. borealis. The study of Alaskan material, however, has disclosed that the presence of cirrus spines cannot be doubted. Since cirrus spination is often used as a specific 
character in cestode differentiation, it is important to evaluate properly this disagreement of observations. The study of all available material of the "borealis" type has shown without doubt that Alaskan specimens are conspecific with those collected farther south. Further, the fact that cirrus spines are sometimes not visible on the Alaskan specimens indicates some kind of irregularity in this character, either actual or resulting from the treatment of the material. After consideration of all possibilities, there is only one tenable conclusion: cirrus spines are often lost through partial degeneration of the cestodes when they are not removed immediately after the death of the host. This conclusion is supported by the statement by Joyeux and Baer (1936), in reference to another species of cestode, Hymenolepis horrida (von Linstow, 1901), that "Le cirre est armé sur toute sa longueur de petits crochets qui peuvent disparâitre dans les échantillons macérés." Schiller's (1952b) study of the same species of Hymenolepis has not only supported Baer's work, but has also disclosed much variation in size of cirrus spines. Various factors contribute to delayed autopsy of animals collected for study. Rate of degeneration of host tissue, with attendant maceration of cestodes in the intestinal tract, depends upon weather and upon host species. The usually cool temperatures of northern Alaska, coupled with the fact that much of the autopsy work was done daily in the field at the time of collection of the mammals seems to have contributed to a greater suitability of the resulting material for study.

That egg size is variable cannot be doubted, although the lessened value of this character in connection with species differentiation contributes further to the already numerous difficulties associated with the identification of anoplocephalid cestodes. Again, as with Andrya macrocephala, there is no graded variation. Egg size differs from one locality to another with no apparent regularity. There is a tendency for Alaskan cestodes to show a greater range in egg size, and a greater average measurement, than do specimens from the central United States.

The additional data on $P$. borealis obtained from the study of the Alaskan material make it clear, in the writer's opinion, that this name refers only to a stage in the growth of $P$. variabilis. The name Paranoplocephala borealis (Douthitt, 1915), consequently becomes a synonym of $P$. variabilis (Douthitt, 1915), which is discussed briefly below.

\section{Paranoplocephala variabilis (Douthitt, 1915)}

Since the foregoing discussion of $P$. borealis applies directly here, only a few additional remarks on $P$. variabilis are necessary. It is evident that $P$. variabilis is a species of wide distribution in North America. It occurs from the Arctic Coast of Alaska south to at least the Lake States, and over this range it parasitizes several species of rodents. The possibility of its occurrence in Eurasia should not be overlooked, although there is at present no evidence that it has Holarctic distribution.

On the basis of gross appearance, $P$. variabilis is readily differentiated by its anteriorly attenuated, elongate strobila from other species of Paranoplocephala occurring in voles (see Rausch and Schiller, 1949a ; Figs. 1 and 4). As mentioned above, $P$. variabilis exhibits considerable morphological variation, much of which is associated with the age of the individual cestode. In common with $P$. infrequens, it exhibits a rather wide range of egg sizes. The eggs of Alaskan specimens ranged 
from 32 to $42 \mu$ long by 30 to $40 \mu$ wide, while those from the United States usually possess smaller eggs. Douthitt (1915; p. 22), for specimens from Geomys, gave the egg size as 30 to $35 \mu$. The specimens studied by Rausch and Schiller (1949a) had smaller eggs, from 26 to $33 \mu$ long by 20 to $26 \mu$ wide. Egg size is too variable to have specific value per se, particularly since such variations are local, and do not show any gradation in relation to geographic distribution.

\section{Paranoplocephala omphalodes (Hermann, 1783)}

Paranoplocephala omphalodes, the type species of the genus, is a well-known vole parasite in Europe. The only authentic record of its occurrence in North America is that of Rausch (1951). According to the writer's observations, $P$. omphalodes is limited to arctic Alaska in its North American distribution. It is a rather common parasite of the narrow-skulled vole, Microtus miurus paneaki, in the central Brooks Range.

The Alaskan specimens of $P$. omphalodes are readily differentiated from the other North American members of the genus on the basis of strobila form. It has a greatly elongate, Andrya-like strobila, with a prominent scolex. Although it superficially resembles Andrya macrocephala, it differs in segment shape, having a relatively high length/width ratio.

Although listed as a separate species in Baer's (1927) monograph of the family Anoplocephalidae, $P$. blanchardi (Moniez, 1891) was considered identical with $P$. omphalodes by Joyeux and Baer (1936). In a later publication (Baer, 1949), the situation is further discussed: "La différence de taille entre ces deux espèces, à première vue si marquée, disparait lorsqu'on possède on matériel suffisant conservé à divers degrés de macération. Les échantillons très contractés atteignent une largeur de $5 \mathrm{~mm}$. tandis que ceux qui sont étirés et macérés, atteignent à peine $1 \mathrm{~mm}$. Chez les deux espèces, la poche du cirre renferme un cirre armé et les oeufs sont munis d'un appareil piriforme. Dans les deux cas, également, on trouve une alternance très irrégulière des pores sexuels qui ne sont jamais complètement unilatéraux."

The conclusion that $P$. blanchardi is conspecific with $P$. omphalodes requires the recognition (in Europe) of two "forms" of $P$. omphalodes, with strobila lengths from "20 à $40 \mathrm{~mm}$. ou 100 à $215 \mathrm{~mm}$.", and with genital pores either "unilatéraux ou irrégulièrement alternes." In North America such a situation is not evident. All material examined by the writer compares well with the description of $P$. omphalodes given by Baer in his earlier publication (1927). Material was adequate in amount, and condition, to allow thorough study.

Since the writer's material is the first of this species to be studied from North American hosts, a short diagnosis of the species is included herewith:

\section{Paranoplocephala omphalodes (Hermann, 1783)}

(Figs. 2-3)

Diagnosis: Strobila length 150 to $195 \mathrm{~mm}$.; maximum width, attained in postmature segments, $4 \mathrm{~mm}$. Strobila ribbon-like, with serrate margins. Segment-number up to 350 . Mature segments occur in narrow, attenuated strobila-section immediately following scolex; length/ width ratio of mature segments about $1: 10$. Length/width ratio of early gravid segments $1: 5$; of late gravid segments $1: 2.7$. Scolex well developed, distinctly set off from neck. Genital pores irregularly alternate, situated in anterior third of segment margin. Testes spherical, 51 to 61 in number, all situated in aporal half of segment. Most porally situated testes rarely in 
contact with aporal limit of ovary. Cirrus sac about 250 by $70 \mu$ in mature segments; cirrus spinose. Internal seminal vesicle present. Vagina postero-ventral to cirrus sac. Stronglylobed ovary situated in poral half of segment. Vitelline gland near middle of ovary, usually somewhat poral. Tubular uterus present in mature segments; uterine growth takes place through development of regular anterior and posterior sacculations. Gravid uterus nearly

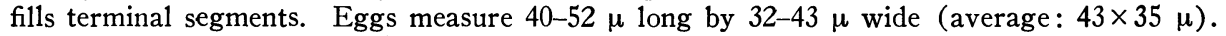

North American host: Microtus miurus paneaki Rausch.

Distribution: Tulugak Lake, Brooks Range, Arctic Alaska. (Lat. $68^{\circ} 20^{\prime}$ N., Long. $151^{\circ} 26^{\prime} \mathrm{W}$.)

Habitat: Small intestine of host.

A slide bearing a complete specimen has been deposited in the Helminthological Collection of the U. S. National Museum, Slide No. 47803.

\section{Paranoplocephala lemmi n. sp.}

At Point Barrow, Alaska, during the early spring of 1949, the writer collected from the brown lemming a few cestodes closely related to $P$. infrequens. In a preliminary report of lemming parasites (Rausch, 1950), these specimens were designated as $P$. infrequens; however, subsequent study of this and additional material has revealed that this species is distinct. It is described herewith as

\section{Paranoplocephala lemmi n. sp.}

(Figs. 4-7)

Diagnosis: Strobila length 10 to $20 \mathrm{~mm}$.; maximum width, attained near posterior end, 3 to $7 \mathrm{~mm}$. Strobila wedge-shaped, often with slight narrowing of terminal gravid segments. Margins serrate; neck short. Length/width ratio of mature segments as great as $1: 16$; little increase in length of gravid segments. Segments number from 68 to 79 . Scolex from 1 to 1.6 $\mathrm{mm}$. in width, very distinct from neck. Suckers powerful. Ventral longitudinal excretory canals about $30 \mu$ in diameter; dorsal canals, lateral to latter, about $20 \mu$ in diameter. Genital pores unilateral; dextral; situated near middle of segment margin. Genital canals dorsal to longitudinal excretory canals. Testes subspherical, 56 to 73 in number (average: 67), about $70 \times 80 \mu$ in mature segments. Testes extend from about middle of vitelline gland to aporal longitudinal ventral excretory canal, or just beyond it, and in earlier mature segments are situated in almost single row across segment; antero-posterior distribution much restricted. Cirrus sac strongly developed; pyriform, from 300 to $720 \mu$ long by 100 to $180 \mu$ wide; cirrus slender, provided with inconspicuous spines. Internal and external seminal vesicles highly developed. Vagina ventral and posterior to cirrus sac. Seminal receptacle well developed. Vitelline gland, variable in shape but usually lobed, situated near center of ovary. Ovary highly lobed, situated in poral half of segment. Tubular uterus in mature segments does not pass laterally beyond longitudinal ventral excretory canals; it does not extend aporally as far as testes. Uterine sacculations gradual in development. Gravid segments not filled by uterus beyond longitudinal excretory canals. Eggs variable in size, nearly spherical, from 51 to $67 \mu$ long by 41 to $56 \mu$ wide (average: $51 \times 58 \mu$ ). Pyriform apparatus well developed; embryo only about $15 \mu$ long.

Type host: Brown lemming, Lemmus trimucronatus alascensis Merriam. Additional hosts: L. t. trimucronatus (Richardson)-Melville Peninsula and Chesterfield Inlet, N. W. T.;

L. t. harroldi (Swarth)-Nunivak Island.

Type locality: Point Barrow, Alaska.

Habitat: Cecum of host.

Type: A whole-mount, containing type and paratype specimens, has been deposited in the Helminthological Collection of the U. S. National Museum, Slide No. 37355.

Discussion: $P$. lemmi n. sp. is closely related to $P$. infrequens, which it resembles in regard to habitat, strobila shape, and morphological details. It differs clearly from this species in strobila size and segment number, in egg size, size of cirrus sac, testes number and distribution, and in character of the uterus. Host occurrence may be diagnostic, according to present knowledge. $P$. lemmi n. sp. may also be limited to the North American arctic in its geographic distribution. 


\section{Genus Andrya Railliet, 1893}

The species of Andrya, so important in the parasite-fauna of microtine rodents, often present unusual difficulties in identification. There is a lack of consistent morphological characters, and variation may be so great as to exceed any but the broadest species definitions. Only four species are now recognized in North America (viz., A. primordialis Douthitt, 1915; A. macrocephala Douthitt, 1915; A. neotomae Voge, 1946; A. sciuri Rausch, 1947). The literature has been reviewed in recent publications (Rausch, 1947; 1948; Rausch and Schiller, 1949b). Three species of Andrya, one of which is described as new, are considered in the present paper.

\section{Andrya macrocephala Douthitt, 1915}

Cestodes regarded as $A$. macrocephala were collected, mainly from species of Microtus, over much of the Territory of Alaska. Variation in morphological details was noted, and this variation exceeded the limits established earlier from the study of material obtained in the United States (Rausch and Schiller, 1949b). The degree of variation in certain characters was found to differ from one locality to another in Alaska, but there was no evidence anywhere of variation of a continuously-graded nature.

In the earlier work by Rausch and Schiller (1949b), it was concluded that egg size, in conjunction with any other characters of apparent taxonomic value (such as testes distribution, relative size of cirrus sac, etc.), was particularly important in the differentiation of species of Andrya. It is now possible to evaluate this character from a much broader standpoint insofar as host-species occurrence and geographical distribution are concerned. For the present study, specimens of $A$. macrocephala collected from New York west to California and Washington, and from Mexico City north to central Alaska and St. Lawrence Island, in the Bering Sea, were available. Over the southern part of North America, specimens exhibited no appreciable disagreement with the diagnosis of $A$. macrocephala as established by Rausch and Schiller (1949b).

Although the cestodes showed considerable uniformity in regard to general morphological details, variation in egg size was especially marked in the Alaskan specimens. A cestode collected about 100 miles southeast of Fairbanks was typical of $A$. macrocephala in every detail, with an average egg size of $33 \times 28 \mu$. Specimens from the same host (Microtus oeconomus macfarlani) collected farther north, at Big Delta, disclosed a larger average egg size, $39 \times 31 \mu$, but otherwise showed no disagreement with $A$. macrocephala. The greatest extremes in egg size were noted in cestodes collected from rodents on St. Lawrence Island. The eggs of specimens from St. Lawrence Island voles, Microtus oeconomus innuitus, ranged in size from 36 to $48 \mu$ long by 27 to $38 \mu$ wide. A good series of cestodes was also obtained from ground squirrels, Citellus parryii lyratus Hall and Gilmore, and in these the greatest extremes in egg size to be recorded in Alaska were seen. These eggs ranged in size from 40 to $51 \mu$ long by 30 to $41 \mu$ wide. The study of these specimens failed to disclose other morphological differences. If knowledge of cestode speciation were more complete, it might in some cases be expedient to utilize a subspecific designation.

Two generalizations appear to derive from these observations on $A$. macroceph- 
Rausch in Journal of Parasitology (October 1952) v. 38, no. 5.

Copyright 1952, American Society of Parasitologists. Used by permission.

ala: (1) Great variation in egg size and egg shape (ovoid to spherical) must be accepted; (2) There is no recognized correlation between morphological variation in $A$. macrocephala and its host-species occurrence.

It becomes obvious that a broad view of this species must be taken, and great care must be exercised in the description of new species of Andrya, unless distinct morphological differences are evident.

\section{Andrya primordialis Douthitt, 1915}

The status of Andrya primordialis was reviewed to complete the study of Alaskan cestodes of the genus Andrya. The examination of all available material has made certain discrepancies obvious in the concept of this species.

Douthitt (1915) described two cestodes, Andrya primordialis and A. communis, and pointed out (page 10) that "Many of the differences in the two accounts are due probably to differences in the state of contraction in the material." In his monograph of the ANoplocephalidae, Baer (1927) concluded that A. communis was identical with $A$. primordialis, and included a revised diagnosis of the latter. Two cestodes from Tamiasciurus hudsonicus Erxleben furnished the basis for the description of $A$. primordialis, while $A$. communis was described from more abundant material, consisting of ". . . about 200 fragments in alcohol and 17 slides" (Douthitt, 1915 ; p. 8), from Clethrionomys gapperi galei Vigors. The present writer has been able to secure, of Douthitt's original material, only serially-sectioned specimens. In the case of $A$. communis, nearly all mounted material available to Douthitt was already sectioned when he received it, since he stated that only a single scolex with "a considerable number of proglottids attached" was examined, thus "furnishing an idea of the appearance of the complete worm."

In any event, Douthitt was unable to give egg size for either of his species, but made some observations on the developing uterus. Baer (1927; p. 35) published an egg size of $35 \mu$ for $A$. primordialis. Dr. Baer (personal communication) is not certain of the origin of this figure, but suggested that it might have been derived from $A$. primordialis var. gundii Joyeux, 1923. The figure also closely approximates the egg size of $A$. macrocephala. Since there has been no subsequent publication of egg size for $A$. primordialis, the description of the species is incomplete.

A pedunculated prostate gland was described by Douthitt for both $A$. primordialis and $A$. communis. This character alone should differentiate $A$. primordialis from the other North American species (viz., $A$. macrocephala Douthitt, $1915 ; A$. neotomae Voge, 1946; $A$. sciuri Rausch, 1947). Of North American species of Andrya, $A$. primordialis is also unique, according to published descriptions, in the possession of unilaterally-arranged genital pores.

For some time the writer has recognized the indefinite status of $A$. primordialis. The examination of several hundred specimens of Andrya spp. has failed to disclose any individuals which correspond to this species as described. Individuals possessing unilateral genital pores have not been observed, although a condition approaching this has been noted in certain Rocky Mountain material. The writer has not been able to determine with certainty the presence of a prostate gland, either from his own material or from Douthitt's material such as could be obtained from the U. S. National Museum collection (a total of seven slides; six of these marked $A$. primordialis and one marked $A$. communis-all serial sections). 
The lack of any egg production in many strobilae further complicates the problem, since in such cases one of the most important differentiating characters-that of egg size-is lost. Even though the range of egg size may be great, it is often significant when considered in relation to other details.

A limited amount of material which seems clearly to represent the species $A$. primordialis has been studied. A specimen was obtained from one of the type hosts, Tamiasciurus hudsonicus, collected in Wyoming. This strobila, about $80 \mathrm{~mm}$. long, showed a normal uterus development in all segments. The eggs measured from 52 to $66 \mu$ long by 40 to $56 \mu$ wide (average : $62 \times 48 \mu$ ). The testes, in most segments included between the ventral excretory canals, numbered from 39 to 55 . The cirrus sac measured from 108 to $135 \mu$ long, by 52 to $66 \mu$ wide (average: $119 \times$ $60 \mu$ ). The slide containing this cestode has been deposited in the Helminthological Collection of the U. S. National Museum, Slide No. 47801.

Considerable material from Phenacomys $i$. intermedius Merriam, from the same locality as above, was also examined. This agreed closely with the specimen from the squirrel.

Without taking into consideration the prostate gland, egg size in combination with other predominant characters serves to differentiate $A$. primordialis from the other species of the genus, their variability notwithstanding. It should be mentioned that few specimens of $A$. neotomae and $A$. scirui exist in collections, so there is little knowledge of their limits of variation. In addition to the 13 specimens of $A$. neotomae collected by Voge (1948) from Neotoma fuscipes ssp., the writer has obtained about 20 specimens from $N$. cinerea Ord, in Oregon. Of $A$. sciuri, only the original material is known. These species appear to be well differentiated.

The writer hesitates to assign any Alaskan specimens of Andrya to the species $A$. primordialis. Still, certain cestodes of relatively small size, agreeing with $A$. primordialis in testes distribution, and having no apparent development of the external seminal vesicle, should perhaps be assigned to this species. The possibility of their being immature or aberrant individuals of $A$. macrocephala cannot be overlooked, however, The solution of this problem is dependent upon the availability of adequate material for study-probably best obtainable in the Rocky Mountain region of the western United States.

\section{Andrya arctica n. sp.}

In the early spring of 1949 , in the course of examination of lemmings (particularly Dicrostonyx) in the vicinity of Point Barrow, the writer collected several cestodes of the genus Andrya which, by virtue of a small, delicate strobila, relatively large cirrus sac, and large eggs, seemed clearly to represent an undescribed species. Later, when the confused status of $A$. primordialis was realized, and since some variation had been seen by this time in the lemming form, the latter was tentatively assigned to the species $A$. primordialis (see Rausch, $1950 ; 1951$ ). The similarity of egg sizes, particularly, brought about this conclusion, since the previous experience with $A$. macrocephala had led the writer to consider this character to be relatively stable. However, after a review of the literature and the study of all available material, it is concluded that the lemming cestode is distinct from $A$. primordialis. It is described herewith as new. 
Rausch in Journal of Parasitology (October 1952) v. 38, no. 5.

Copyright 1952, American Society of Parasitologists. Used by permission.

Andrya arctica n. sp.

(Figs. 8-9)

Diagnosis: Strobila 50 to $145 \mathrm{~mm}$. long; maximum width, attained near posterior end of strobila, 1 to $2.4 \mathrm{~mm}$. Mature segments often as long as broad, but extreme ratio of length to width may be as great as $1: 5$. Scolex from 215 to $560 \mu$ wide, strongly set off from thin neck; suckers about 80 by $110 \mu$. Segmental margins serrate. Genital pores irregularly alternate, situated in the posterior third of the segment margin. Cirrus sac strongly developed, from 194 to $352 \mu$ long by 57 to $136 \mu$ wide in mature segments. Cirrus sac often extends across $1 / 3$ of segment width. Cirrus spinose. Internal and external seminal vesicles strongly developed. Testes usually from 40 to 50 in number; about $80 \mu$ in diameter in mature segments. Testes extend, in the extreme, from proximal end of cirrus sac to well beyond aporal longitudinal ventral excretory canal. Testes in some cases not seen farther poral than poral edge of ovary. Entire anterior field of segment occupied by testes. Prostate gland absent. Vagina posterior to cirrus sac; very large seminal receptacle, usually spherical in shape, seen in post-mature segments. This organ often extends well into following segment. Ovary situated in middle of segment, near posterior edge. Vitelline gland, relatively large, situated at posterior margin of segment, near middle; its width may equal as much as $1 / 4$ of mature segment width. Uterine development clearly reticulate; development somewhat asymmetrical, with posterior extension more rapid on aporal side. Terminal segments completely filled with large eggs; excretory canals usually not persistent in gravid segments. Eggs measure (not in a single strobila) from 40 to $72 \mu$ long by 26 to $65^{\mu} \mu$ wide. The average egg size is about $65 \times 50 \mu$. Normal egg shape ranges from ellipsoid to spherical, within the same segment.

Type host: Dicrostonyx groenlandicus rubricatus (Richardson). Also collected from $D$. groenlandicus richardsoni Merriam-Churchill, Manitoba; D. groenlandicus ssp.-Prince Patrick Island; Lemmus trimucronatus alascensis (Merriam)-Point Barrow, Alaska ; Clethrionomys rutilus dazesoni (Merriam)-Umiat, Alaska; Microtus miurus paneaki Rausch-Umiat, Alaska.

Type locality: Point Barrow, Alaska.

Type: A slide bearing an entire specimen has been deposited in the Helminthological Collection of the U. S. National Museum, Slide No. 37356.

Discussion: Andry arctica n. sp. clearly belongs in the subgenus Aprostatandrya as it was originally defined by Kirschenblatt (1938). ${ }^{1}$ This in itself eliminated $A$. primordialis from consideration, its present controversial status notwithstanding. The writer is unwilling to emend the specific diagnosis of $A$. primordialis, beyond the point of egg size discussed above, without clear-cut evidence.

To the best of the writer's knowledge, the subgenus Aprostatandrya Kirschenblatt, 1938, contains the following species: Palearctic- $A$. africana Baer, $1933 ; A$. monodi Joyeux and Baer, 1930; Nearctic-A. macrocephala Douthitt, 1915; $A$. neotomae Voge, 1946; A. sciuri Rausch, 1947. In another publication (Rausch and Schiller, 1949b), A. caucasica Kirschenblatt, 1938, was provisionally considered identical with $A$. macrocephala. According to the published description, $A$. biatowienzensis Soltys, 1947, possesses a prostate gland and need not be considered here.

$A$. arctica can be readily differentiated from $A$. monodi and $A$. africana on the basis of testes distribution, as well as relative organ size differences. From $A$. neotomae and $A$. sciuri, $A$. arctica differs in relative organ size, egg size, and testes distribution. From $A$. macrocephala it differs essentially in egg size and relative size of cirrus sac.

It is possible that adaptation to host species (it is predominantly a parasite of lemmings) and geographical distribution (arctic North America) also have some specific significance. A single specimen of cestode in the writer's collection, from Lemmus lemmus L., collected at Enontekis, Finland, possibly should be referred to this species, but the available material does not allow certainty in this. A. arctica

${ }^{1}$ Recently, Russian workers have given Kirschenblatt's subgenera full generic standing. The writer does not agree with this concept. 
Rausch in Journal of Parasitology (October 1952) v. 38, no. 5.

Copyright 1952, American Society of Parasitologists. Used by permission.

must therefore be considered an helminth restricted in its distribution to the North American Arctic until evidence to the contrary is obtained.

\section{Genus Catenotaenia Janicki, 1904}

The genus Catenotaenia is not well represented in Alaska, either from the standpoint of species or of individuals. Only one species-C. reggiae Rausch, 1951-occurs commonly as a parasite of a hoary marmot, Marmota caligata broweri Hall and Gilmore, in the arctic Brooks Range region.

\section{Catenotaenia dendritica (Goeze, 1782)}

Collected but once from a red-backed vole, Clethrionomys rutilus dawsoni, near Anchorage, Alaska, this cestode is a rare parasite of microtine rodents in the Territory. The single specimen obtained was typical. The writer has collected this parasite also from C. gapperi cascadensis Booth, from the state of Washington. With possible local exceptions, it is not a common parasite in North American microtine rodents.

\section{Genus Paruterina Fuhrmann, 1906}

Cestodes of the genus Paruterina are, in the adult stage, parasitic in birds. According to present knowledge, $P$. candelabraria (Goeze, 1782) is the only species for which mammals serve as the intermediate host. It is a widely-distributed, circumpolar species (Wolffhügel, 1900), particularly common in Alaska in the snowy owl, Nyctea scandiaca (L.).

\section{Paruterina candelabraria (Goeze, 1782)}

Although the larval stage of this owl parasite was not actually observed in any of the rodents examined, it was nevertheless a common parasite of the snowy owl along the Arctic Coast of Alaska. The writer found 29 of these owls infected, of 112 individuals autopsied. These birds were all collected along the Arctic Coast from Wainwright to Point Barrow, with the exception of two specimens from St. Lawrence Island. This cestode has been recorded by the writer, also, from the hawk-owl, Surnia ulula caparoch (Müller), Richardson's owl, Aegolius funereus richardsoni (Bonaparte), and the saw-whet owl, $A$. acadicus acadicus (Gmelin), all from southern Alaska. In view of the life-cycle requirements of this cestode (Rausch, 1949), it is evident that microtine rodents in northern Alaska must serve as its intermediate host.

It was remarked by Rausch (1949) that the cysticercoids of $P$. candelabraria were unknown from natural infections of rodents. The writer has since been advised by Dr. Reino Freeman, Department of Zoology, Southern Illinois University, that he has collected naturally-infected rodents in Minnesota. Dr. Freeman expects to publish the details of his observations.

\section{Genus Hymenolepis Weinland, 1858}

Cestodes of the genus Hymenolepis were poorly represented in the material collected from Alaskan and north Canadian microtine rodents. Only two species, $H$. horrida (von Linstow, 1901) and H. johnsoni Schiller, 1952a, have been collected. 
Rausch in Journal of Parasitology (October 1952) v. 38, no. 5.

Copyright 1952, American Society of Parasitologists. Used by permission.

\section{Hymenolepis horrida (von Linstow, 1901)}

A well-known parasite of Eurasian voles, Hymenolepis horrida was first recorded from North American rodents by Kuns and Rausch (1950). The present investigation has shown it to be perhaps the most common and widespread cestode parasite of boreal rodents on the continent. Farther south it is rare, occurring mainly in voles found in sub-alpine or alpine habitats (Rausch, 1951); however, further investigation is required to clarify the characteristics of its occurrence beyond the limits of boreal spruce forest.

The abundant material obtained in connection with this work has been studied by Mr. E. L. Schiller, of this laboratory. His work disclosed the occurrence of rather extreme morphological variation in $H$. horrida, which has necessitated a modification of the species-concept (Schiller, 1952b).

\section{Hymenolepis johnsoni Schiller, 1952}

Four specimens of a cestode, recently described by Schiller (1952a) as Hymenolepis johnsoni, were obtained from a vole, Microtus pennsylvanicus drummondii, trapped at Fort Rae, on Great Slave Lake. No other record of this cestode has been obtained. Since nothing is known of the species beyond the original description, further discussion of it here is not warranted.

\section{Genus Echinococcus Rudolphi, 1810}

Cestodes of the genus Echinococcus are important parasites of canine animals throughout Alaska. Only on St. Lawrence Island is the life-cycle of a cestode of this genus connected with microtine rodents.

\section{Echinococcus sp.}

The occurrence of the larval form of Echinococcus sp. in voles, Microtus oeconomus innuitus, on St. Lawrence Island, was reported by Rausch and Schiller (1951). Subsequent studies on this island have shown further that a red-backed vole, Clethrionomys rutilus albiventer, is also an important intermediate host of this cestode. The red-backed vole, however, has not been abundant during the time of these observations (1950-52); only three specimens, two infected, have been obtained.

St. Lawrence Island lies in the Bering Sea just off the Siberian Coast, and there is considerable evidence that the species of Echinococcus found there is of Asiatic origin. This hypothesis is particularly tenable when one considers that the Echinococcus situation on Bering Island, in the Komandorskii group, appears to be epizootiologically identical with that on St. Lawrence Island. On Bering Island, $C$. rutilus is the intermediate host. In this regard, Barabash-Nikiforov (1938) stated that ". . . almost 50 per cent of these animals are infested with an intermediate stage of Taenia echynococcus." More important were the observations of Afanas'ev (1941), who considered Evotomys rutilus (=C. rutilus) the only intermediate host of "Echinococcus granulosus (Batsch)" on the Island. He also made numerous observations on slaughtered domestic animals (cattle, swine, reindeer), but failed to find any of these infected. Afanas'ev found no trace of this parasite on Mednii Island, and considered it absent here because the red-backed vole also was absent. (“. . . po prichine otsutstviia tam ego promezhutochnogo khoziaina-polevki.”) 
Bering Sea currents unquestionably are such that mammals are transported on floating ice from Siberia to St. Lawrence Island. A full discussion of this point will be included in a later report.

The species of Echinococcus occurring on St. Lawrence Island differs at least immunologically from the mainland form, which the writer regards as E. granulosus (Batsch, 1786). On the Alaskan mainland, where Echinococcus is a common parasite of canine animals, the intermediate hosts are moose and caribou. There is no record of natural rodent infection by the larval form of this cestode on the mainland.

Cross-infection experiments, using mainland material as well as that from the Island, have substantiated field observations relative to peculiarities of intermediate-host occurrence. Observations on a variety of experimental animals (cricetids, murids, sciurids, geomyids) to which infective eggs were administered have supported the conclusion that voles are readily infected by the St. Lawrence Island species, but no success has been achieved in the infection of rodents with mainland material. To date, wild-caught Microtus californicus (from California), laboratory-reared $M$. pennsylvanicus, wild-trapped C. rutilus dawsoni (Alaskan main-

TABLE 3.-Measurements of Adult Specimens of Echinococcus from Alaskan Canine Hosts

\begin{tabular}{|c|c|c|c|c|c|c|c|}
\hline \multirow{2}{*}{ Host } & \multirow{2}{*}{ Locality } & \multirow{2}{*}{$\begin{array}{l}\text { Strobila } \\
\text { length } \\
\text { (in mm.) }\end{array}$} & \multirow{2}{*}{$\begin{array}{l}\text { Segment } \\
\text { number }\end{array}$} & \multicolumn{2}{|c|}{$\begin{array}{l}\text { Hook size } \\
\text { (in microns) }\end{array}$} & \multicolumn{2}{|c|}{$\begin{array}{c}\text { Egg size } \\
\text { (in microns) }\end{array}$} \\
\hline & & & & Large & Small & Range & Average \\
\hline Dog & Point Barrow & $2-3$ & $2-3$ & $\ldots \ldots$ & & $35-40 \times 28-32$ & $37 \times 29$ \\
\hline Dog & Anchorage & $3-4$ & $3-4$ & $\ldots \ldots$ & $\ldots \ldots$ & $32-37 \times 30-32$ & $35 \times 30$ \\
\hline Dog & Unalakleet & $2-3$ & 3 & 40 & $32-35$ & $32-35 \times 29-30$ & $33 \times 29$ \\
\hline Dog & Point Barrow & Imm. & Imm. & 35 & 24 & $\ldots \ldots \ldots \ldots$ & $\ldots \ldots$ \\
\hline Wolf & $\begin{array}{l}130 \text { Miles N. E. } \\
\text { Anchorage }\end{array}$ & $2-2.2$ & $2-3$ & & & $34-40 \times 29-34$ & $36 \times 31$ \\
\hline Red fox & Nunivak Island & $1-1.4$ & 3 & 27 & 22 & $34-43 \times 30-35$ & $36 \times 32$ \\
\hline Red fox & Point Barrow & 1 & $2-3$ & 38 & 24 & $35-40 \times 32-38$ & $38 \times 35$ \\
\hline Dog & St. Lawrence Island & $1.5-2.3$ & $3-4$ & $26-27$ & 22 & $32-38 \times 29-34$ & $34 \times 30$ \\
\hline Arctic fox & St. Lawrence Island & $1.2-1.9$ & $3-4$ & 29 & 25 & $30-34 \times 29-30$ & $31 \times 29$ \\
\hline
\end{tabular}

land), a wild-caught muskrat, Ondatra zibethica ssp. (Alaskan mainland), and wildtrapped Peromyscus sp. (from California), have been successfully infected using the St. Lawrence Island form.

Morphological differences between the adult stages of the two forms are not evident. In fact, the importance of adult morphology in the taxonomy of this genus of cestodes is not clear. The writer has at hand adult specimens representing at least six species of Echinococcus. These will be studied later in relation to the Alaskan material, and a separate report will be made. It is of interest to note the wide range of variation seen in the Alaskan specimens. This is summarized in Table 3. The following points are evident:

1. Strobila ranges in length from 1 to $4 \mathrm{~mm}$., with segment number from 2 to 4 (rarely 5). when a gravid terminal segment is present.

2. Strobila size is possibly related to size of definitive host on mainland of Alaska. On St. Lawrence Island cestodes characterized by a very small strobila occur in both dogs and arctic foxes.

3. There is much variation, from one mainland locality to another, in size of rostellar hooks.

4. Form of gravid uterus is highly variable; it may range from branched to 
Rausch in Journal of Parasitology (October 1952) v. 38, no. 5.

Copyright 1952, American Society of Parasitologists. Used by permission.

sac-like. This character may be too variable to have value in species differentiation.

5. Egg-size of Alaskan material varies within definite limits (30-43 $\mu$ long by 28-38 $\mu$ wide) ; however, both range- and average-size variation differ in degree from one locality to another.

Clear-cut morphological differences are evident when the larval cestodes from St. Lawrence Island (from voles) are compared with those of the mainland form (from moose). Moose, so commonly parasitized by this helminth in southern Alaska, often show severe lung infections; the writer has observed as many as 18 cysts, up to $5 \mathrm{~cm}$. in diameter, in the lungs of an old animal. Such cysts are typically spherical in shape, surrounded by a well-defined wall of host tissue-reaction. The germinal membrane is intimately associated with the surrounding connective-tissue capsule, but is readily freed when the cyst is incised. Many scolices occur in such a cyst, but they appear to arise directly from the germinal membrane; they are often attached to one another in groups by fragile strands of tissue, best seen in the living specimen. There has been no case observed where cyst formation tended toward any other structural arrangement. Secondary cysts within the large primary cyst have not been observed. In the moose, Echinococcus larvae occur regularly in the lungs, and the writer has not observed them in other locations in this host.

Larval cestodes observed in naturally-infected voles had characteristic multilocular structure, best described as an aggregation of small cysts, usually from 1 to $4 \mathrm{~mm}$. in diameter, coalesced into an amorphous mass whose shape is largely determined by the character of the organ in which it occurs. The larval mass typically shows an evenly-granulated surface, but in some cases somewhat larger cysts may occur peripherally. Cyst size is apparently regulated by the process of reproductive growth.

While most experimentally infected voles (Microtus californicus, M. pennsylvanicus, and Clethrionomys rutilus) showed cyst growth identical to that seen in the naturally infected animals, one specimen of $M$. pennsylvanicus, killed 45 days after infection, showed an aggregation of larger, mostly single, cysts situated mainly on the parietal liver surface. Two other species of rodents, a muskrat (Ondatra zibethica) and a white-footed mouse (Peromyscus sp.) contained larvae of the same type. Since, in all cases, the larvae were normally developed (i.e., had produced large numbers of scolices), the significance of larval differences is not understood.

In every infected rodent so far examined, the invasion-center was the liver; beyond this, larvae were occasionally found in other organs, or attached along the mesenteries. Lung cysts in voles were never observed. In voles the liver is invaded in every case, and insofar as the writer has been able to determine, the liver infections precede all others. The secondary cysts must reach their site of localization after their derivation from the initial infection. This probably occurs through the rupture of earlier-established cysts, or possibly through metastasis. The latter method does not seem likely, but further study of the problem is necessary.

On the tenth day after experimental infection of voles, larval growth, seen as minute peripheral foci, was visible on the parietal liver surface. Voles killed and examined on the 20th day showed many isolated cysts of 1 to $3 \mathrm{~mm}$. in diameter. These were well distributed throughout the organ. The study of these 20-day-old 
infections showed clearly that reproduction occurred through the subdivision of the vesicle-like cysts. The primary cysts, each apparently arising from a single egg, showed internal septa which would result eventually in the production of many cysts from each. Scolex formation could not be observed on the 20th day after infection; however, after 40 days, scolices were numerous.

The rate of larval growth is surprisingly rapid in the case of vole infections, and this seems characteristic of the vole-infecting form of Echinococcus. A redbacked vole autopsied on the 40th day after infection disclosed a greatly enlarged liver, which caused extreme abdominal distension. This infected organ actually weighed more than the remainder of the animal's body. A similar situation was observed in a second animal, a specimen of $M$. pennsylvanicus, which finally succumbed to the combined effect of liver damage and pressure from the greatlyenlarged organ. Such animals are greatly hampered in their activity by the size of the infected liver, and no doubt in nature often become readily-captured prey for foxes and other animals feeding upon them.

\section{Genus Taenia Linné, 1758}

Two species of the genus Taenia whose larval stages are harbored by microtine rodents have been recorded from Alaska. These are T. tenuicollis Rudolphi, 1809, a common parasite of certain mustelids, particularly the ermine, Mustela erminea arctica (Merriam), and T. crassiceps Rudolphi, 1810, a parasite of the arctic fox, Alopex lagopus innuitus (Merriam), recorded here for the first time from North America.

\section{Taenia tenuicollis Rudolphi, 1809}

Abundant material of the larval form of $T$. tenuicollis has been collected from Alaskan voles and lemmings. These cysticerci were often observed in Clethrionomys rutilus dawsoni, Lemmus trimucronatus alascensis, and Microtus miurus paneaki. Comparisons of larval hook size and shape with these characters in the adult stage leaves no doubt as to specific identity. A limited range of variation in hook size was noted.

In earlier publications (Rausch and Tiner, 1949; Rausch, 1950), these cysticerci were tentatively assigned to Cladotaenia. This opportunity is taken to call attention to these erroneous reports.

It is necessary also to revise the earlier opinion that natural infections of Cladotaenia spp. are commonly observed. It is, on the contrary, more comparable to Paruterina candelabraria in regard to relative frequency of detected occurrence. Two possibilities are obvious: Either such larvae are overlooked in the rodent hosts, or the relatively high incidence of infection of hawks and owls by these cestodes is only the result of the consumption of an enormous number of rodents, among which infected animals are few.

\section{Taenia crassiceps Rudolphi, 1810}

Several hundred cysticerci of Taenia crassiceps were found free in the body cavity of a lemming, Dicrostonyx groenlandicus richardsoni, collected at Churchill, Manitoba. Another, but less heavy, infection was seen in a brown lemming, Lemmus $t$. trimucronatus, from the Melville Peninsula. Taenia crassiceps was the 
Rausch in Journal of Parasitology (October 1952) v. 38, no. 5.

Copyright 1952, American Society of Parasitologists. Used by permission.

most abundant cestode parasite of the arctic fox along the Arctic Coast of Alaska, but the larval stage has never been found in Alaskan rodents. Baer (1946) stated that its larvae are found "dans le tissu cellulaire sous-cutane de la region auxillaire ou inguinale" in rodents; this would lessen the probabilities of their being observed in the course of routine autopsy. The same author stated that the occurrence of these cysticerci in the host body cavity is rare.

The comparison of North American cestodes, both larval and adult stages, with European specimens, supplied by Dr. J. G. Baer, showed good agreement in morphological details. Another cestode parasite of European foxes, T. polyacantha Leuckart, 1856 , closely resembles $T$. crassiceps in both adult and larval stages. The larvae may be differentiated, however, by the exogenus reproduction of $T$. crassiceps. This characteristic is well illustrated by Baer and Scheidegger (1946; p. 62). Although the asexual reproduction of the cysticerci was not as evident in the North American material as in that from Europe, it was nevertheless clearlydefined, and it is assumed that the large number of larvae recovered from the specimen of Dicrostonyx had resulted from this type of reproduction. A cysticercus of $T$. crassiceps from Dicrostonyx is shown in Fig. 10. A vial containing examples of these cysticerci has been deposited in the Helminthological Collection of the U. S. National Museum, accession No. 47804.

The record by Baer (1946) of the infection of a monkey by T. crassiceps is of considerable interest, since it gives further evidence that this cestode is not limited to rodent intermediate hosts. The possibility of human infection should not be disregarded, particularly since Eskimo-arctic fox relationships are often such that human exposures would be likely.

Since $T$. crassiceps has not been hitherto recorded from North America, a description of the adult cestode is included herewith. Hall (1920) reported Taenia sp. from the arctic fox on St. George Island (Pribilof group), but apparently no specific determination has been made of cestodes from this host species in North America.

\section{Taenia crassiceps Rudolphi, 1810}

(Figs. 11-13)

Diagnosis: Strobila length from 70 to $140 \mathrm{~mm}$.; greatest width, slightly over $1 \mathrm{~mm}$., attained in post-mature segments. Strobila margins serrate. Mature segments only slightly longer than wide; segment length increases toward end of strobila; gravid segments about four times as long as wide. Scolex relatively small, about $700 \mu$ in diameter; oval suckers about $200 \mu$ long. Rostellum armed with usually 30 hooks, arranged in two rows. Large hooks 172 to $178 \mu$ long; small hooks 121 to $136 \mu$ long. Genital pores irregularly alternate, situated in anterior half of segment margin. Genital papillae prominent. Cirrus sac from 160 to $215 \mu$ long by 50 to $70 \mu$ wide. Cirrus sac does not overlap ventral longitudinal excretory canal. Vas deferens highly coiled. Subspherical testes, about 220 in number, arranged in two lateral fields so as to have greatest number in anterior half of segment; testes distribution continuous across anterior part of segment. Narrow but unbroken row of testes extends from one field to the other just posterior to vitelline gland at posterior edge of segment. Testes about $50 \mu$ in diameter in mature segments, do not overlap ventral longitudinal excretory canals; they closely surround bilobed ovary and vitelline gland. Vagina, opening posterior to cirrus sac, has uniform narrow diameter and takes direct course postero-mediad. Two reniform ovarian masses present; aporal one always larger. Each consists of relatively fine lobulations. Vitelline gland approximates ovarian masses in size. Ovary and vitelline gland situated completely in posterior segment-half. Uterus extends anteriorly into posterior part of preceding segment. Lateral uterine branches first appear as rounded outgrowths, which develop more rapidly at anterior end of main uterine stem. Lateral branches number about 20 on each side, often with terminal subdivisions. Eggs abundant, 25 to $32 \mu$ long by 22 to $27 \mu$ wide. 
Rausch in Journal of Parasitology (October 1952) v. 38, no. 5.

Copyright 1952, American Society of Parasitologists. Used by permission.

North American host: Arctic fox, Alopex lagopus innuitus (Merriam) and A. lagopus ssp. North American distribution: Arctic Coast of Alaska and St. Lawrence Island.

Habitat: Small intestine of host.

A slide containing a whole-mount has been deposited in the Helminthological Collection of the U. S. National Museum, No. 47802.

The North American material does not correspond exactly in morphological detail to specimens from European foxes. The diagnosis given by Joyeux and Baer (1936) disagrees particularly in hook size and testes number. The differences, however, fall into the range of normal variation and are not considered significant.

\section{TREMATODA}

\section{Genus Quinqueserialis Skvortsov, 1934}

Four species of the genus Quinqueserialis, all parasitic in microtine rodents, are currently considered valid: Q. quinqueserialis (Barker and Laughlin, 1911); Q. hassalli (McIntosh and McIntosh, 1934); Q. wolgaensis Skvortsov, 1934; Q. floridensis Rausch, 1952. The genus was reviewed by Harwood (1939) and, more recently, by Ruiz (1946) in his revision of the family Pronocephalidae Looss, 1902.

\section{Quinqueserialis quinqueserialis (Barker and Laughlin, 1911)}

This trematode is a common parasite of Alaskan muskrats, but has been collected from voles (Microtus pennsylvanicus drummondii and M. oeconomus macfarlani) from only three widely separated localities (Arctic Village, Big Delta, and along the Skwentna River.) Adequate material was obtained to make possible comparisons with trematodes from both hosts collected in the United States. This opportunity is taken to make some remarks on relationships within the genus Quinqueserialis.

Few characters are of value in the differentiation of the species of this genus. Important among these are: number of glands in the ventral rows; form and distribution of the vitellaria; length of metraterm in relation to cirrus sac length; egg size. The North American species appear to be well characterized, although two of them show considerable morphological variation.

The Alaskan specimens of $Q$. quinqueserialis varied in size to a marked degree - the largest specimens occurred in voles, while relatively small ones were harbored by the muskrat. This was noted when specimens were collected from both muskrats and voles in the same locality. Size differences are often seen in material collected from muskrats in the United States; this is in part connected with the age of the trematodes.

Since the present work is concerned only with the mouse-like microtine rodents, the trematodes from muskrats were not studied in detail. The following observations were made on a good series of $Q$. quinqueserialis from Microtus pennsylvanicus drummondii from the Skwentna River near Anchorage, Alaska:

1. Considerable flexibility was noted in the number of glands in the ventral rows. The lateral rows had from 14 to 18 ; the paramesal rows, from 14 to 17 ; the median row, from 15 to $18 .^{2}$

${ }^{2}$ Gland counts were made on trematodes stained entire with fast green and studied, unmounted, in terpineol. 
Rausch in Journal of Parasitology (October 1952) v. 38, no. 5.

Copyright 1952, American Society of Parasitologists. Used by permission.

2. The distribution of vitelline follicles ranged from that characteristic of $Q$. quinqueserialis to that seen in $Q$. hassalli-i.e., from a single row of follicles situated dorsal to the lateral gland row to more numerous follicles aggregated in a broader row, with at,least a good proportion situated lateral to the lateral gland row.

3. The metraterm length ranged from 55 to 83 per cent of that of the cirrus sac.

4. Egg size ranged from 16 to $21 \mu$ long by 8 to $11 \mu$ wide; egg shape showed little variation.

It appears that the species $Q$. quinqueserialis tends toward intergradation with $Q$. hassalli. The number of glands in each ventral row has been thought to have particular diagnostic value, but even in Harwood's review of the genus, it was stated that this character is subject to considerable variation. False impressions have perhaps arisen through the failure to recognize variation of a local nature, such as is shown by other helminths for which a greater volume of material has been available for study. The writer is of the opinion at present that egg size and egg shape differ in the two species, $Q$. hassall $i$ having a smaller and less elongate egg. Conclusions cannot be drawn at this time, but thorough study of these two species, preferably with experimental infections, should be made.

The status of $Q$. wolgaensis is somewhat questionable. Insofar as the writer is aware, it has not been recorded since it was described by Skvortsov (1934), who obtained it from Arvicola terrestris (L.) near Gorky, in the valley of the Volga River. From the description, it is evident that $Q$. wolgaensis is morphologically similar to both $Q$. quinqueserialis and $Q$. hassalli. Skvortsov was unaware of the existence of $Q$. hassalli when he prepared the description of $Q$. wolgaensis, since he stated (page 321) that “... only one American species, Notocotylus quinqueserialis Barker and Laughlin, 1914, has five rows of them" [i.e., ventral glands]. Skvortsov's figure 1 (page 319) and his description do not support Harwood's statement $(1939 ;$ p. 430) that $Q$. wolgaensis may be separated from the two closely-related species on the basis of vitelline follicle distribution. Skvortsov stated (page 321) that his species differed from $Q$. quinqueserialis "... in shape of the body, in the number of papillae in the longitudinal series, in the size of the bursa of cirrus and in the size of the vagina."

In the original description, $Q$. wolgaensis has 14-15 glands in the middle row and 15 in paramesal and lateral rows. Although Skvortsov had 81 specimens of this trematode, it is possible that he failed to make gland counts on a large enough series to determine the ranges. According to the original figure, the metraterm is about half the length of the cirrus sac; this ratio is subject also to considerable variation. The eggs of $Q$. wolgaensis, 18 to $22 \mu$ long by 9 to $12 \mu$ wide, are almost identical in size with those of $Q$. quinqueserialis.

One will not be able, without material for comparative study, to determine the status of $Q$. wolgaensis; the possibility should be kept in mind, however, that $Q$. wolgaensis is conspecific with $Q$. quinqueserialis. $Q$. quinqueserialis may occur naturally in Eurasia, but in any event the muskrat, along with its parasites, has been widely introduced there from North America. Warwick (1936), for example, has recorded Q. quinqueserialis from the muskrat in Great Britain. 


\section{Genus Plagiorchis Lühe, 1899}

Plagiorchis sp.

Two specimens of Plagiorchis sp. were taken from the small intestine of a red-backed vole, Clethrionomys rutilus dawsoni, trapped near Anchorage, Alaska. In North America, only P. proximus Barker, 1915, from the muskrat, has been recorded from microtine rodents. Two species of Plagiorchis have been reported from Eurasian voles; these are P. arvicolae Shul'ts and Skvortsov, 1931, from Arvicola amphibius L., and P. microti Sołtys, 1947, from Microtus arvalis Pallas. Plagiorchis sp. was also reported by Warwick (1936) from $A$. amphibius in the British isles.

The Alaskan vole specimens in some respects resemble $P$. proximus Barker, 1915, which occurs commonly in Alaska as a muskrat parasite. A brief description of the trematodes from the vole is included herewith (Fig. 14) :

Length $1.5 \mathrm{~mm}$. Subterminal oral sucker equal in size to acetabulum; latter in first body third. Anterior edge of ovary at posterior margin of acetabulum. Testes and ovary nearly equal in size. Vitellaria extend from posterior end of body to beyond posterior margin of oral sucker; laterally they overlap testes' margins and extend dorsally nearly across body width at anterior limit of their distribution. Cirrus sac, about $320 \mu$ long, extends from genital pore posteriad beyond anterior margin of ovary. Uterus typical. Eggs, somewhat distorted, measure about $34 \times 16 \mu$.

A whole mount has been deposited in the Helminthological Collection of the U. S. National Museum, Slide No. 47812.

Genus Brachylaima Dujardin, 1843

Brachylaima rauschi McIntosh, 1951

This trematode was observed only as a very local parasite of microtine rodents. Few specimens were obtained, and nothing can be added here to the original description. An erroneous type locality was designated; this should be Tulugak Lake, Anaktuvuk Pass, in the Brooks Range. In addition to the type host, Dicrostonyx groenlandicus rubicatus, this trematode was also collected from Microtus miurus paneaki.

Trematodes of the family Brachylaimidae apparently do not often parasitize microtine rodents. The writer has obtained Brachylaima sp. from Microtus pennsylvanicus terraenovae Bangs, Penguin Island, Newfoundland; these specimens, six in number, have been given to Mr. Allen McIntosh, Zoological Division, Burean of Animal Industry, for study. Entosiphonus thompsoni Sinitsin, 1931, was reported by Rausch and Tiner (1949) from $M$. p. pennsylvanicus, from southern Wisconsin.

\section{NEMATODA}

\section{Genus Heligmosomum Railliet and Henry, 1909 Heligmosomum costellatum (Dujardin, 1845)}

Heligmosomum costellatum was first reported from North American rodents by Kuns and Rausch (1950), who collected it from voles trapped in subalpine habitats in the Rocky Mountains of Wyoming. The present work has shown it to be a widely distributed parasite of various species of voles in Alaska. Since a detailed description of this nematode was given in the earlier paper (1950), nothing further is included here. 
Heligmosomum hudsonius Cameron, 1937

This species was described from "Dicrostonyx hudsonius" from northern Quebec and Baffin Island by Cameron (1937). The original material had been preserved when it came into Dr. Cameron's hands, so no observations were made on the living organism. Nothing can be added here to the original description, except for remarks on the living worms.

The writer has collected $H$. hudsonius from a single locality in Alaska. A heavy infection was observed in Dicrostonyx groenlandicus rubricatus collected at Tulugak Lake in the Brooks Range. The nematodes were tightly spiralled around the greatly elongate cecal villi of the lemming, and did not release their attachment when placed in situ into cold water. The nematodes were blood-red in color when alive.

\section{Genus Nematospiroides Baylis, 1926}

Nematodes of the genus Nematospiroides are rather common parasites of voles over most of North America. N. longispiculatus Dikmans, 1940, appears to be the most widely distributed. However, it would be desirable to determine the limits of variation in the species of this genus, in order to be able to characterize them adequately. The writer is of the opinion that morphological variation in this group is much greater than is generally recognized at present.

Mr. Merle Kuns, Department of Biology, Purdue University, has studied the Alaskan Nematospiroides material in connection with his review of the family Heligmosomidae, and the writer is indebted to him for the identifications included here. His work has been delayed in its completion by military service; for that reason specific names cannot be included in some cases.

\section{Nematospiroides longispiculatus Dikmans, 1940}

The only record of $N$. longispiculatus was obtained at Juneau, where it was found in a common vole, Microtus longicaudus littoralis. It apparently is replaced farther north by another species.

\section{Nematospiroides spp.}

A single species of Nematospiroides was found over most of Alaska as a parasite of Microtus spp. The description of this nematode has been completed by Mr. Kuns, who will publish it separately.

The writer collected a few specimens of Nematospiroides from Lemmus trimucronatus alacensis, at Point Barrow. These specimens may represent a distinct species. Mr. Kuns made the following comment (personal communication) on these: “. . Nematospiroides sp. [from the lemming] is similar to [that from Alaskan voles] except for generally larger size in nearly all respects. More material is needed on the latter so that an effort can be made to determine if this is only a host difference rather than a specific one." These specimens will be considered in detail in the published report of Mr. Kuns.

The writer has not collected Nematospiroides from voles in the localities where it occurs in lemmings. If this is eventually accomplished, it should permit better evaluation of the size differences. 


\section{Genus Syphacia Seurat, 1916 \\ Syphacia obvelata (Rudolphi, 1802)}

Over most of Alaska, Syphacia obvelata is an abundant rodent nematode parasite. It is found wherever voles occur, and its absence along the central Arctic Coast region can be correlated with vole distribution. No discussion of the morphological details of this species is justified, since specimens collected were typical.

\section{Syphacia arctica Tiner and Rausch, 1950}

Of the lemmings (Dicrostonyx) examined at Point Barrow, a good proportion was found to be infected by Syphacia arctica. In addition, one infected collared lemming was collected at Tulugak Lake, in the Brooks Range. Large numbers of brown lemmings (Lemmus) were also examined along the Arctic Coast, but this parasite was not found in them; it is considered, consequently, to be specifically adapted to Dicrostonyx. This is one of the few instances where, in connection with this study, evidence for rigid specificity of an helminth parasite for a given host has been obtained. Nothing can be added to the original description in way of morphological details.

\section{Genus Rictularia Frölich, 1802}

Nematodes of the genus Rictularia are important parasites of several mammalian groups (see Dollfus, 1944-45). In North America, sciurids frequently harbor nematodes of this genus, but microtine rodents are rarely parasitized by them. The report by Rankin (1945) of a single specimen of $R$. coloradensis Hall, 1916, in Microtus longicaudus, in Washington, apparently constitutes the only record. Rictularia occurs locally in Alaskan voles, but has not been found in sciurids (Citellus parryii) in the same localities.

\section{Rictularia microti McPherson and Tiner, 1952}

Massive Rictularia infections were observed in St. Lawrence Island voles, where as many as 119 nematodes were taken from a single animal. As is characteristic of the group, male individuals were relatively few; in the two heaviest infections noted, with 112 and 119 worms, eight and nine males, respectively, were present. The material from St. Lawrence Island formed the basis for the description of $R$. microti by McPherson and Tiner (1952).

Rictularia sp. was recorded several times from Microtus miurus paneaki and once from Clethrionomys rutilus dawsoni at Tulugak Lake, Brooks Range.

It has not been determined whether the Brooks Range specimens are conspecific with $R$. microti. In reference to the former ( $M$. miurus paneaki), Tiner (personal communication) stated: "In general, specimens from $M$. miurus paneaki were in agreement with the Island males and females from $M$. oeconomus innuitus. However, the buccal cavity was circular in cross section in both sexes from the mainland, whereas the stoma of the male from the Island had a circular cross section and that of the female was roughly oval. The long axis of this oval extended dorsoventrally. There were about 20 denticles in the members of each sex from the mainland. One male from the mainland had four pre-cloacal fans and spicules about $160 \mu$ long. Two other males agreed with those from the Island in that they lacked pre-cloacal fans." $\mathrm{He}$ also is of the opinion that ". . . it would be highly in- 
advisable to speciate Rictularia on the basis of the male specimens until much larger series have been studied for each species."

Since the Brooks Range specimens were obtained from voles trapped in a very restricted sedge-bog habitat, adequate material may not be obtainable. The fact that both forms occur in voles suggests a close relationship. Tiner has pointed out the possibility that the periodic fluctuations in vole populations would greatly influence the nematode populations also; the chance survival of individuals with certain characters might result in a relatively homozygous and uniform species on St. Lawrence Island, since it is completely isolated from the Alaskan mainland.

Genus Mastophorus Diesing, 1853

Mastophorus muris (Gmelin, 1790)

Mastophorus muris was a locally common parasite of red-backed voles in Alaska. It was restricted to spruce forest habitats. In the writer's experience, $M$. muris is not a general parasite of North American voles; in Michigan, where a few infected voles were collected, it was found in but one locality (Rausch and Tiner, 1949).

In reference to Clethrionomys rutilus dawsoni on the Seward Peninsula of Alaska, Quay (1951) reported that "... some of the vole stomachs contained many large nematodes." It seems probable that these were $M$. muris. This nematode was recorded from $C$. rutilus in Norwegian Lapland by Baylis (1931).

Protospirura glareoli Sołtys, 1947 [= Mastophorus glareoli (Sołtys, 1947)] was described from Clethrionomys glareolus Schreber, in Poland. It is differentiated from $M$. muris on the basis of position of vaginal opening, spicule length, and labial characters.

\section{Genus Capillaria Zeder, 1800} Capillaria sp.

One specimen of Capillaria sp. was collected from a red-backed vole, Clethrionomys rutilus dawsoni, trapped at Kotzebue, Alaska. Specific determination was not possible. From Bering Island, in the Komandorskii group, a single specimen, also unidentified, was obtained by the writer from one of three voles of the same species.

Only $C$. muris-sylvatici (Diesing, 1851) has been recorded from Nearctic voles. It occurred as a locally-common parasite in southern Wisconsin (Rausch and Tiner, 1949). Intensive studies in other regions will no doubt disclose the presence of this species, as well as others.

\section{Unidentified nematode}

A minute nematode was obtained from the eyes of brown lemmings at Point Barrow. These were first collected by Mr. Daniel Q. Thompson, of the University of Missouri, who observed them during the course of his studies on lemming ecology. Present material does not permit identification; however, the writer expects to investigate this parasite further at Point Barrow in the spring of 1952. Information presently available indicates a direct life cycle.

\section{SUMMARY}

An investigation of the helminth parasites of microtine rodents of Alaska and northern Canada has been carried on for three years. A total of 2078 rodents of 26 
species and subspecies was examined. Twenty-eight species of helminths were considered, of which Paranoplocephala lemmi n. sp., and Andrya arctica n. sp., (type locality for both Point Barrow, Alaska), were described. Taenia crassiceps Rudolphi, 1810, was recorded for the first time from North America. Taxonomic discussions are included for each species considered.

\section{ACKNOWLEDGMENTS}

The writer is indebted to the following persons for important aid in connection with this study: Messrs. E. L. Schiller and B. B. Babero, of this laboratory, and Drs. P. J. Brandly and J. D. Tiner, formerly of this laboratory, have assisted with the the Alaskan mammal collecting and laboratory work; Mr. C. O. Handley, Jr., of the Division of Mammals, U. S. National Museum, made available parasites of lemmings from Prince Patrick Island; Dr. George P. Holland, Division of Entomology, Department of Agriculture, Ottawa, Canada, kindly made available important rodent material from Chesterfield Inlet, N. W. T., and from Swedish Lapland; Mr. W. B. Quay, Division of Mammals, University of Michigan, furnished specimens of rodents from both Old World and North American localities; particular appreciation is expressed to Dr. David H. Johnson, Associate Curator of Mammals, Division of Mammals, U. S. National Museum, who very generously made available the viscera of certain preserved rodents otherwise unobtainable; Mr. W. Earl Godfrey, Canadian National Museum, provided a collection of rodents from Alberta; Mr. Ralph B. Williams, Director of Laboratories, Alaska Department of Health, aided with rodent trapping in the vicinity of Juneau; personnel of the U. S. Fish and Wildlife Service in Alaska have contributed material. To all of these, and to others who have from time to time furnished Alaskan rodent material, the best thanks is expressed.

\section{REFERENCES}

Afanas'ev, V. P. 1941 Parazitofauna promyslovykh mlekopitaiushchikh Komandorskikh Ostrovov. Uchenie Zapiski, Seriia biologicheskikh Nauk. 18: 93-117.

Baer, J. G. 1927 Monographie des cestodes de la famille des Anoplocephalidae. Bull. Biol. France et Belgique, suppl. 10, pp. 1-241.

1949 Contributions à la faune helminthologique africaine. Acta Tropica 6: 41-45. AND Scheidegger, S. 1946 Un cas intéressant de tétraplégie d'origine parasitaire. Schweiz. Zeitschr. Path. u. Bakt. 14: 61-66.

Barabash-Nikiforov, I. 1938 Mammals of the Commander Islands and the surrounding sea. J. Mammal. 19: 423-429.

BAYlis, H. A. 1931 Notes on some parasitic worms from Norwegian rodents. Ann. \& Mag. Nat. Hist. Ser. 10, 7: 175-176.

Cameron, T. W. M. 1937 A new species of Heligmosominae from the Labrador collaredlemming. Raboti po gel'mintologii. pp. 66-68. Moscow.

Dollfuss, R. Ph. And Desportes, C. 1944-5 Sur le genre Rictularia Froelich 1802 (Nematodes Spiruroidea). Ann. Parasitol. 20: 6-34.

Douthit, H. 1915 Studies on the cestode family Anoplocephalidae. Illinois Biol. Monogr. 1: $355-446$.

Hall, M. C. 1920 Intestinal parasites found in eighteen Alaskan foxes. Amer. Vet. 1: 123124.

Harkema, R. 1946 The Metazoa parasitic in cotton rats of Wake County (N. C.). Abst. rept. 43rd Ann. Mtg. N. C. Acad. Sci. in J. Elisha Mitchell Sci. Soc. 62: 142-143.

Harwood, P. D. 1939 Notes on Tennessee helminths. IV. North American trematodes of the subfamily Notocotylinae. J. Tenn. Acad. Sci. 14: 421-437.

Joyeux, Ch. And Baer, J. G. 1936 Cestodes. Faune de France 30. 613 pp. Paris.

Kirschenblatt, J. D. 1938 Die Gesetzmässigkeiten der Dynamik der Parasitenfauna bei den mäuseähnlichen Nagetieren (Muriden) in Transkaukasien. Diss. Univ. Leningrad, pp. 5-92. 
Rausch in Journal of Parasitology (October 1952) v. 38, no. 5.

Copyright 1952, American Society of Parasitologists. Used by permission.

Kuns, M. L. ANd Rausch, R. 1950 An ecological study of helminths of some Wyoming voles (Microtus spp.) with a description of a new species of Nematospiroides (Heligmosomidae: Nematoda). Zoologica, N. Y. Zool. Soc. 35: 181-188.

McIntosh, A. 1950 Brachylaima rauschi n. sp. from an arctic lemming. J. Parasit. 36 (suppl.) : 20 .

- And McIntosh, G. E. 1934 A new trematode, Notocotylus hassalli n. sp. (Notocotylidae), from a meadow mouse. Proc. Helm. Soc. Wash. 1: 36-37.

McPherson, S. ANd Tiner, J. D. 1952 A new nematode (Rictularia microti) from a vole on St. Lawrence Island, Alaska. Nat. Hist. Miscellanea, No. 108, pp. 1-7.

Ognev, S. I. 1948 Zveri SSSR i prilezhashchikh stran (zveri vostochnoi Evropy i severnoi Asii). vol. VI, 588 pp. Moscaw-Leningrad.

Quay, W. B. 1951 Observations on mammals of the Seward Peninsula, Alaska. J. Mammal. 32: 88-99.

Rankin, J. S. 1945 Ecology of the helminth parasites of small mammals collected from Northrup Canyon, Upper Grand Coulee, Washington. Murrelet 26: 11-14.

$\rightarrow$ Rausch, R. 1947 Andrya sciuri n. sp., a cestode from the northern flying squirrel. J. Parasit. 33: 316-318.

$\rightarrow-1948$ Notes on cestodes of the genus Andrya Railliet, 1883, with the description of A. ondatrae n. sp. (Cestoda: Anoplocephalidae). Trans. Amer. Micr. Soc. 67: 187191.

1949 Observations of the life cycle and larval development of Paruterina candelabraria (Goeze, 1782) (Cestoda: Dilepididae). Amer. Midl. Nat. 42: 713-721.

1950 Observations on a cyclic decline of lemmings (Lemmus) on the Arctic Coast of Alaska during the spring of 1949. Arctic 3: 166-177.

1951 Biotic interrelationships of helminth parasitism. Public Health Repts. 66: 928-934.

$\rightarrow-1952$ Helminths from the round-tailed muskrat, Neofiber alleni nigrescens Howell, with descriptions of two new species. J. Parasit. 38: 151-156.

ANd Schiller, E. L. 1949a Some observations on cestodes of the genus Paranoplocephala Luehe, parasitic in North American voles (Microtus spp.) Proc. Helm. Soc. Wash. 16: 23-31.

$\rightarrow-$ AND $\longrightarrow 1949 \mathrm{~b}$ A critical study of North American cestodes of the genus Andrya with special reference to $A$. macrocephala Douthitt, 1915. (Cestoda: Anoplocephalidae). J. Parasit. 35: 306-312.

AND 1951 Hydatid disease (Echinococcosis) in Alaska and the importance of rodent intermediate hosts. Science 113 (no. 2925) : 57-58.

And Tiner, J. D. 1948 Studies on the parasitic helminths of the North Central States. I. Helminths of Sciuridae. Amer. Midl. Nat. 39: 728-747.

AND 1949 Studies on the parasitic helminths of the North Central States. II. Helminths of voles (Microtus spp.). Preliminary report. Amer. Midl. Nat. 41: 665-694.

RuIz, J. M. 1946 Pronocephalidae (Trematoda). Estudos das especies brasileiras e revisão da familia. Mem. Inst. Butantan 19: 249-372.

ScHILler, E. L. 1952a Hymenolepis johnsoni n. sp., a cestode from the vole (Microtus pennsylvanicus drummondii). J. Wash. Acad. Sci. 42: 53-55.

1952b Studies on the helminth fauna of Alaska. X. Morphological variation in Hymenolepis horrida (von Linstow, 1901) [Cestoda: Hymenolepididae]. J. Parasit. (in press).

Skvortsov, A. A. $1934 \mathrm{~K}$ izucheniiu gel'mintofauny vodianykh krys Arvicola terrestris (L). Vestnik Mikrobiologii Epidemiologii i Parazitologii 13: 317-326.

Soltys, A. 1947 Pasozyty wewnetrzne drobnych gryzoni lesnych (Muridae) Parku Narodowego w Białowiezy. Ann. Univ. Mariae Curie-Sklodowska 4: 233-259.

TINeR, J. D. ANd Rausch, R. 1950 Two new Syphacia (Nematoda: Oxyuridae) and observations on the inner circle circumoral papillae in North American species of the genus. Nat. Hist. Miscellanea no. 57; pp. 1-6.

$\rightarrow$ Voge, M. 1946 A new anoplocephalid cestode, Andrya neotomae from the wood rat Neotoma fuscipes. J. Parasit. 32: 36-39.

1948 A new anoplocephalid cestode. Paranoplocephala kirbyi, from Microtus californicus californicus. Trans. Amer. Micr. Soc. 67: 299-303.

WARWICK, T. 1936 The parasites of the muskrat (Ondatra zibethica L.) in the British Isles. Parasitol. 28: 395-402.

WolfFH ÜGEL, K. 1900 Beitrag zur Kenntnis der Vogelhelminthen. Inaug. Diss. Basel. 204 pp. 
Rausch in Journal of Parasitology (October 1952) v. 38, no. 5.

Copyright 1952, American Society of Parasitologists. Used by permission.

\section{Explanation of Plates}

Figures drawn by Miss Reggie V. Sacressen, technical assistant, Animal-borne Disease Branch, Arctic Health Research Center. All figures from projected whole-mounts.

\section{Plate I}

Fig. 2. Paranoplocephala omphalodes, mature segment. Scale has value of $500 \mu$.

FIG. 3. $P$. omphalodes, pregravid segment, showing characteristic uterus development. Scale has value of $500 \mu$.

Fig. 4. P. lemmi n. sp., mature segment. Scale has value of $250 \mu$.

FIG. 5. P. lemmi n. sp., scolex. Scale has value of $500 \mu$.

FIG. 6. P. lemmi n. sp., entire strobila. Scale has value of $5 \mathrm{~mm}$.

FIg. 7. P. lemmi n. sp., details of cirrus sac and vagina. Scale has value of $500 \mu$.

\section{Plate II}

Fig. 8. Andrya arctica n. sp., mature segment. Scale has value of $500 \mu$.

FIG. 9. A. arctica n. sp., scolex. Scale has value of $200 \mu$.

FIG. 10. Taenia crassiceps, cysticercus. Scale has value of $500 \mu$.

FIG. 11. T. crassiceps, mature segment. Scale has value of $250 \mu$.

FIG. 12. T. crassiceps, rostellar hooks. Scale has value of $50 \mu$.

FIG. 13. T. crassiceps, gravid segment. Scale has value of $1 \mathrm{~mm}$.

Fig. 14. Plagiorchis sp. Scale has value of $500 \mu$. 
Rausch in Journal of Parasitology (October 1952) v. 38, no. 5.

Copyright 1952, American Society of Parasitologists. Used by permission.
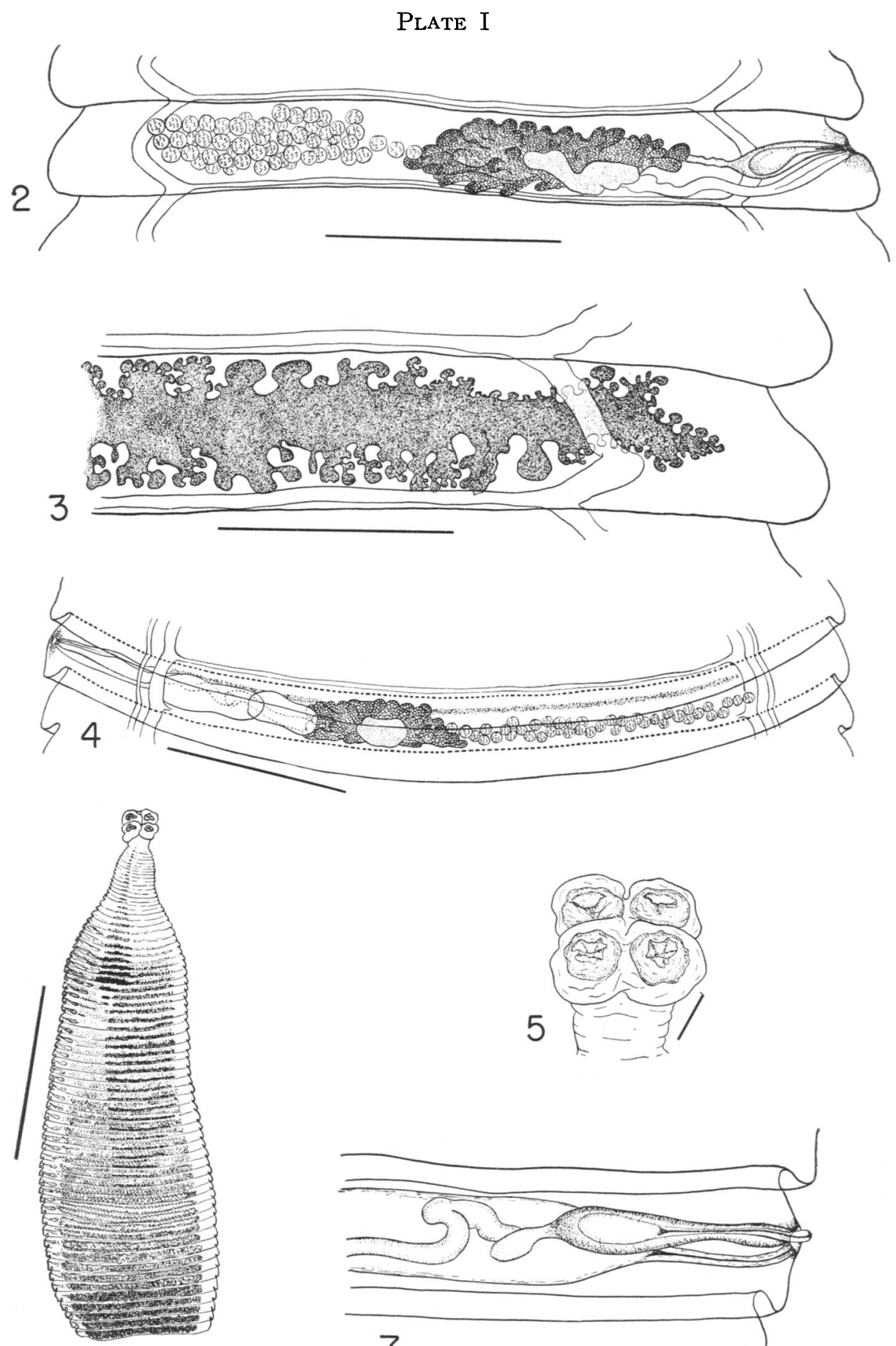

6
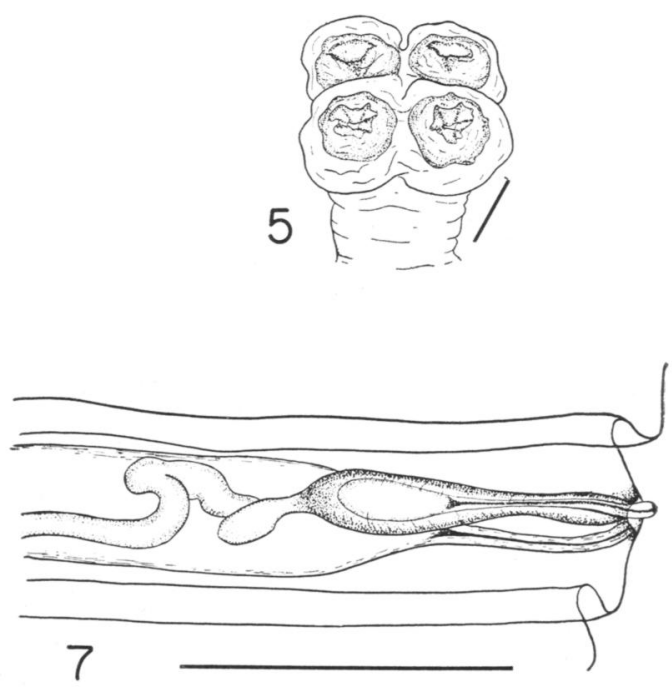
Rausch in Journal of Parasitology (October 1952) v. 38, no. 5.

Copyright 1952, American Society of Parasitologists. Used by permission.

Plate II
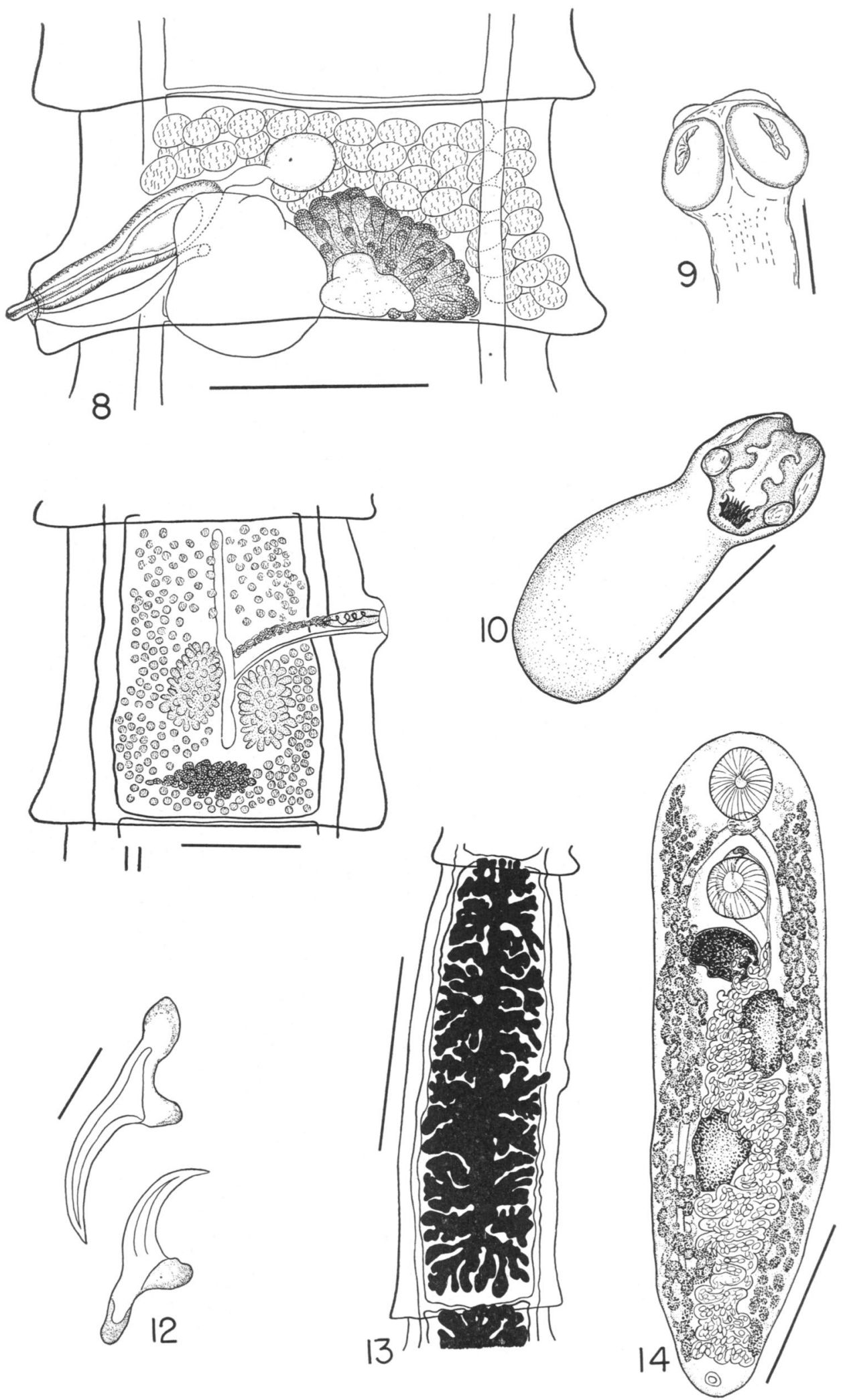